\title{
A Serra da Capivara e os primeiros povoamentos sul-americanos: uma revisão bibliográfica
}

The Serra da Capivara area and the first settlements in South America: a bibliographical review

\author{
Antoine Lourdeaul, II, III (1) \\ 'Muséum National d'Histoire Naturelle. Paris, França \\ "Universidade Federal de Sergipe. Laranjeiras, Sergipe, Brasil \\ '"'Fundação Museu do Homem Americano. São Raimundo Nonato, Piaú, Brasil
}

\begin{abstract}
Resumo: A área da Serra da Capivara (Piauí, Brasil) é famosa na comunidade arqueológica internacional, principalmente pela polêmica ao redor do sítio Pedra Furada e de suas datas do Pleistoceno superior, fazendo dele um dos sítios mais antigos das Américas. Os dados oriundos deste sítio contribuem indiscutivelmente nas discussões e nos conhecimentos sobre os processos de povoamento do continente. Por outro lado, a concentração das atenções sobre ele e sobre os debates provocados ofuscaram numerosas pesquisas nesse local que forneceram uma impressionante quantidade de dados sobre as primeiras ocupações humanas nas mais variadas áreas de conhecimento. No presente artigo, a partir de uma revisão bibliográfica, sintetizamos os resultados dessas pesquisas quanto aos contextos e aos comportamentos dos grupos humanos que ocuparam a região durante o final do Pleistoceno superior e o Holoceno inicial. Mostramos, assim, como a pré-história da Serra da Capivara dialoga com os grandes temas sobre o povoamento do continente americano e traz uma contribuição relevante sobre essas questões, nas escalas macrorregionais e continentais.
\end{abstract}

Palavras-chave: Povoamento. Pré-história. Nordeste do Brasil. Tecnologia lítica. Pleistoceno final. Holoceno inicial.

Abstract: The Serra da Capivara area (Piauí, Brazil) is famous among archaeologists, mainly because of the controversy over the Pedra Furada shelter and its dates from the upper Pleistocene, making it one of the oldest sites in the Americas. The data from this site undoubtedly contributed to discussions about the settlement processes on the continent. On the other hand, the concentration of attention on this site and the resulting debates overshadowed numerous investigations in the Serra da Capivara, wich provided an impressive amount of data on the first human occupations in a variety of knowledge areas. This article reviews the literature to summarize the results of this research on the contexts and behaviors of the human groups that occupied the region during the late Pleistocene and early Holocene showing how the prehistory of Serra da Capivara dialogues with the overarching themes related to the settlement of the Americas and makes a relevant contribution on these issues, at the macro-regional and continental levels.

Keywords: Settlement dynamics. Prehistory. Northeast of Brazil. Lithic technology. Final Pleistocene. Early Holocene.

LOURDEAU, Antoine. A Serra da Capivara e os primeiros povoamentos sul-americanos: uma revisão bibliográfica. Boletim do Museu Paraense Emílio Goeldi. Ciências Humanas, Belém, v. 14, n. 2, p. 367-398, maio-ago. 2019. DOI: http://dx.doi.org/10.1590/1981.812 22019000200007.

Autor para correspondência: Antoine Lourdeau. Muséum National d'Histoire Naturelle. Musée de I'Homme. UMR 7194, 17 Place du Trocadéro. Paris, França, 75116 (antoine.lourdeau@mnhn.fr).

Recebido em 22/10/2018

Aprovado em 28/01/2019

(c) (i)

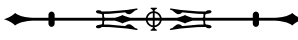




\section{INTRODUÇÃO}

A região conhecida como Serra da Capivara cobre parte dos municípios de São Raimundo Nonato, Coronel José Dias, João Costa e Brejo do Piauí, no sudeste do Piauí. O Parque Nacional Serra da Capivara, criado em 1979, abrange a maior parte dessa área (Figura 1) (Pessis; Guidon, 2007).

A unidade de relevo mais marcante é uma tortuosa linha de falésias areníticas, que se desenvolve em um eixo sudoeste-nordeste em mais de $50 \mathrm{~km}$. Do ponto de vista geomorfológico, trata-se de um front de Cuesta, que delimita um pedimento ao sudeste e uma chapada ao noroeste (Figura 2). O pedimento é uma ampla planície levemente entalhada pela rede hidrográfica da bacia do rio Piauí, com um substrato de rochas pré-cambrianas (micaxisto, gnaisse, granito, calcário). O calcário apresenta-se na forma de inselbergs, que constituem relevos cársticos dispersos na planície, localmente chamados de 'serrotes'.

O substrato da chapada é composto de interestratificações de arenito, siltito e conglomerado de seixo do Siluriano e Devoniano, expostos no relevo ruiniforme do front de Cuesta e nos profundos canyons que recortam esse platô. Os cursos d'água, hoje intermitentes, formaram vales de orientação sul-norte, seguindo a declividade progressiva da chapada. $\bigcirc$ maior deles é o vale conhecido como Serra Branca, localizado a oeste do Parque Nacional.

O desnível entre pedimento e chapada é de 200 a $250 \mathrm{~m}$, mas, com a Cuesta sendo dupla, com um tabuleiro intermediário, a altura das falésias não passa de 150 m (Arnaud et al., 1984; Pellerin, 2014).

O clima atual é semiárido e a vegetação é de 'caatinga', com fisionomia arbustiva decídua na chapada e no pedimento, e arbórea semidecídua nas áreas mais sombreadas do front de Cuesta e dos canyons, onde certa umidade permanece o ano todo (Emperaire, 1983). Os dados paleoambientais locais apontam para momentos de umidade bem mais marcada do que o atual no final do Pleistoceno e no início do Holoceno (Chaves, 2002; Santos, J., 2007; Mota, 2017). Esses resultados condizem com as

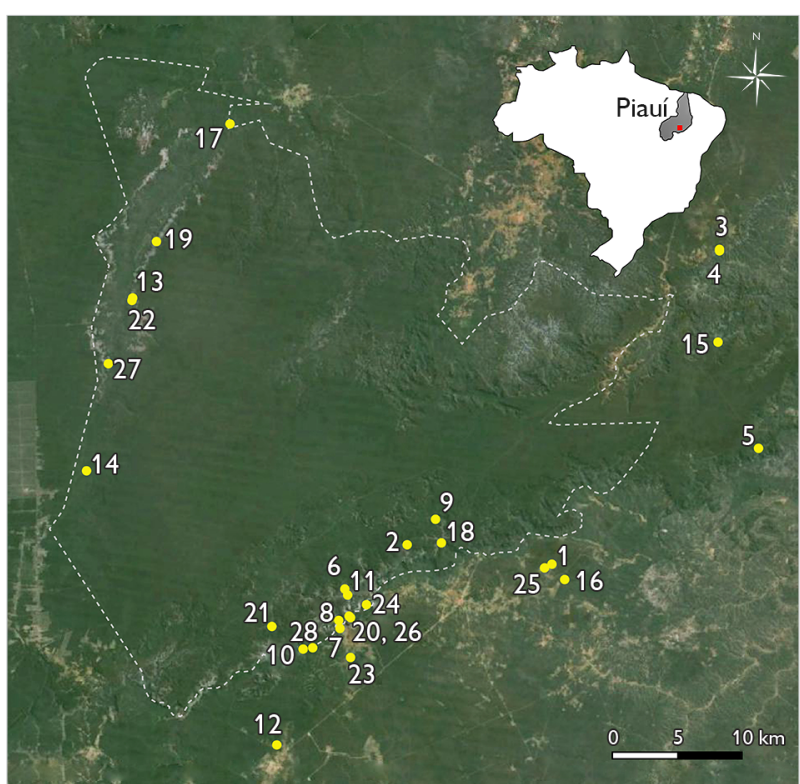

Figura 1. Mapa de localização dos principais sítios arqueológicos da Serra da Capivara (Piauí), datados do Pleistoceno final e do Holoceno inicial. A linha tracejada refere-se à delimitação do Parque Nacional. Nomes dos sítios: 1 = Antonião; 2 = Baixa das Cabaceiras; 3 = Boa Vista I; $4=$ Boa Vista II; $5=$ Bojo I; $6=$ Caldeirão do Rodrigues I; 7 = Cerca do Elias; 8 = Coqueiros; 9 = Deitado; 10 = Ema do Sítio do Brás I; 11 = Fundo do Baixão da Pedra Furada; 12 = Garrincho; 13 = Inharé; 14 = João Leite; 15 = Justino Aquino IV; 16 = Moendas; $17=$ Morcego; $18=$ Paraguaio; 19 = Pau Doia; 20 = Pedra Furada; $21=$ Perna I; 22 = Pica-Pau; 23 = Pilão; 24 = Sítio do Meio; 25 = Tira-Peia; 26 $=$ Vale da Pedra Furada; $27=$ Vento; $28=$ Zé Luis. Foto: satélite, GoogleEarth (2016).

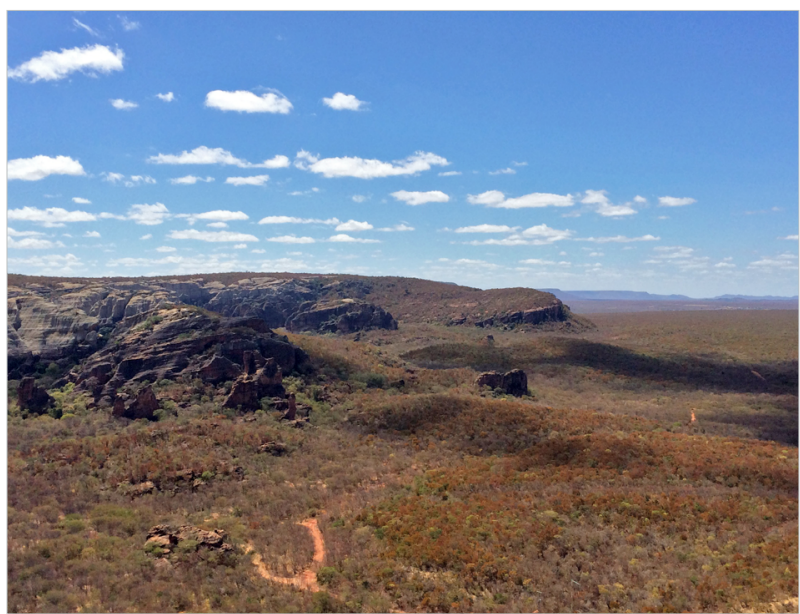

Figura 2. Vista do front de Cuesta no sul do Parque Nacional Serra da Capivara. O relevo ruiniforme separa a chapada (à esquerda) do pedimento (à direita). Foto: L. Lucas (2016).

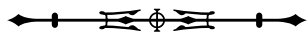


informações disponíveis para o Nordeste, indicando maior umidade e adensamento da vegetação em correspondência com os eventos de Heinrich, especificamente no último, ao final do Pleistoceno, e um declínio da umidade ao longo do Holoceno (Behling et al., 2000; Ledru et al., 2006; Wang et al., 2004). Em termos faunísticos, jazidas pleistocênicas em cavernas calcárias e lagoas forneceram 60 espécies de mamíferos, entre as quais constam 26 espécies fósseis (Guérin et al., 1993; Guérin; Faure, 2014). O espectro indica também uma umidade importante, assim como a existência de áreas arbóreas e outras mais abertas.

Nesse ambiente físico diversificado, centenas de sítios arqueológicos foram encontrados. A maioria é composta por abrigos com pinturas rupestres nos paredões areníticos do front de Cuesta e dos desfiladeiros da chapada. Eles estão sendo estudados desde os anos 1970, quando Niède Guidon e sua equipe começaram a pesquisar na área (Arnaud et al., 1984; Guidon, 1991). Escavações arqueológicas foram realizadas inicialmente com objetivo principal de contextualizar essas produções gráficas.

O desenvolvimento das escavações levou a novas temáticas de pesquisa. Uma das mais importantes, em termos de impacto na comunidade científica, foi a problemática acerca do primeiro povoamento do continente. Em Sítio do Meio (Guidon; Andreatta, 1980) e em Pedra Furada, logo em seguida (Guidon, 1981), as escavações expuseram camadas arqueológicas com idades antigas, incompatíveis com a então predominante teoria do povoamento das Américas. Segundo esse modelo, a presença humana no continente não passava de 13.000 anos, quando, em Pedra Furada, encontravam-se vestígios antrópicos passando dos 30.000 anos antes do presente (Guidon; Delibrias, 1986), podendo ter até 50.000 anos (Parenti, 2001)!

Um importante conjunto de dados sobre os primeiros períodos da pré-história brasileira foi revelado na Serra da Capivara desde o final dos anos 1990 (Guidon et al., 1994, 1998). No entanto, esses dados foram pouco levados em consideração nas sínteses macrorregionais e continentais. Por ser o mais antigo e ter sido o objeto de uma detalhada monografia (Parenti, 2001), Pedra Furada é o principal sítio que reteve o interesse nessas sínteses, participando dos debates sobre o povoamento das Américas há mais de 30 anos (Dillehay, 1999; Goebel et al., 2008; Politis et al., 2008).

Um esforço de síntese dos aportes das pesquisas nas últimas décadas, na região, foi realizado recentemente (Pessis et al., 2014). Em paralelo, as pesquisas de campo sobre os períodos antigos tiveram nova dinâmica, com a realização do programa de pesquisa franco-brasileiro intitulado "Espaços e tempos dos primeiros homens do Piauí", a partir de 2008 (Boëda et al., 2014a, 2014b, 2014c, 2016; Lahaye et al., 2013, 2015).

A presente contribuição é decorrente desse novo impulso de pesquisas e perspectivas. A partir de uma revisão bibliográfica, propomos sintetizar os dados adquiridos na Serra da Capivara sobre os mais antigos momentos de presença humana. Discutiremos também a maneira como se integram com as grandes temáticas sobre os primeiros povoamentos do continente, avaliando as contribuições dessa riquíssima área arqueológica para nosso conhecimento acerca das ocupações iniciais da América do Sul.

Para tal projeto, estruturamos nosso texto ao redor de três questões centrais nessa temática: 1) a cronologia dos povoamentos; 2) os dados paleoantropológicos (a partir dos restos esqueletais humanos); 3) as características dos comportamentos humanos na diacronia. A faixa cronológica escolhida aqui abrange os primeiros indícios de atividade antrópica, no Pleistoceno final e no Holoceno inicial, até aproximadamente 8.000 anos antes do presente'.

\footnotetext{
Salvo menção contrária, todas as datas aqui apresentadas são dadas em 'Antes do Presente' (AP) (o presente sendo o ano de 1950, por convenção) e 'calibradas', quando se tratam de datas radiocarbônicas. Neste artigo, a calibração das datas publicadas não calibradas foi feita pelo programa OxCal, usando a curva SHCal 13
}

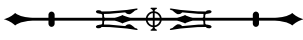




\section{O POVOAMENTO PLEISTOCÊNICO}

\section{UM POVOAMENTO ANTERIOR À TRANSIÇÃO PLEISTOCENO-HOLOCENO²}

$\mathrm{Na}$ abundante bibliografia sobre o primeiro povoamento, o modelo Clovis First prevaleceu durante toda a segunda metade do século $X X$. Segundo ele, os primeiros americanos eram compostos por grupos de caçadores de mamíferos de grande porte originários da Sibéria e caracterizados por uma ponta de projétil acanelada (a ponta Clóvis). Esses grupos se desenvolveram na América do Norte entre 13.300 e 12.800 cal AP (Haynes, 2002; Waters; Stafford Júnior, 2007). Sempre existiram reinvindicações relativas a uma presença humana mais antiga do que a cultura Clóvis no continente (Bryan, 1986), mas, até o final do século $X X$, essa visão foi considerada como minoritária (Lynch, 1990; Haynes únior, 1969).

Nas duas últimas décadas, no entanto, com novos descobrimentos (entre outros fatores), a situação inverteu-se. O modelo Clovis First não é mais satisfatório para explicar a variedade e a antiguidade dos dados arqueológicos, antropológicos e genéticos disponíveis nas Américas (Bonnichsen et al., 2005; Graf et al., 2013). Uma idade mais antiga do que 13.000 anos para a chegada do homem no continente é agora amplamente aceita. Discussões permanecem quanto, por exemplo, ao processo de povoamento (Braje et al., 2017; Potter et al., 2018), mas a maioria dos trabalhos de síntese publicados recentemente coloca esse limite entre, aproximadamente, 20.000 e 15.000 anos antes do presente, baseando-se em dados arqueológicos e genéticos, principalmente (Waters; Stafford Júnior, 2014; Raghavan et al., 2015).

Quatro sítios da Serra da Capivara enquadram-se dentro da faixa cronológica entre 18.000 e $14.000 \mathrm{cal}$ AP. Trata-se de um abrigo e um sítio a céu aberto do front de Cuesta - Sítio do Meio e Vale da Pedra Furada -, de um sítio em maciço calcário - Tira-Peia -, junto com outro possível sítio em caverna calcária - Garrincho.

Sítio do Meio foi o primeiro lugar da Serra da Capivara onde foram encontrados testemunhos antrópicos 'pré-Clovis' (Guidon; Andreatta, 1980). Esse abrigo com pinturas rupestres apresenta, na parte interna, a sequência estratigráfica sintetizada no Quadro 1 e na

Quadro 1. Síntese da sequência estratigráfica do Sítio do Meio a partir de Melo (2007), Aimola et al. (2014) e Boëda et al. (2016).

\begin{tabular}{|c|c|c|}
\hline Descrição das camadas & Cronologia & Correspondências na bibliografia \\
\hline $\begin{array}{c}4^{\circ} \text { - Conjunto de camadas lenticulares arenosas, } \\
\text { com carvão e cinza }\end{array}$ & \multirow{2}{*}{$\begin{array}{c}6.000 \\
\mathrm{a} \\
17.500 \mathrm{cal} \mathrm{AP}\end{array}$} & $\begin{array}{l}\text { Unidade A - Melo (2007, p. 309) } \\
\text { VI - Aimola et al. (2014, figura 4) }\end{array}$ \\
\hline $\begin{array}{c}3^{\circ} \text { - Conjunto de camadas lenticulares de cascalho } \\
\text { com seixos de quartzo dentro de uma matriz } \\
\text { arenosa }\end{array}$ & & $\begin{array}{l}\text { Camadas B1 a B4 - Melo (2007, p. 309) } \\
\text { V - Aimola et al. (2014, figura 4) } \\
\text { Upper unit - Boëda et al. (2016, figura 3) }\end{array}$ \\
\hline $\begin{array}{l}2^{\circ} \text { - Espesso nível de desabamento com blocos de } \\
\text { arenito caídos do teto do abrigo }\end{array}$ & - & $\begin{array}{c}\text { Camadas B5 e B6 - Melo (2007, p. 309) } \\
\text { IV - Aimola et al. (2014, figura 4) } \\
\text { Collapsed blocks - Boëda et al. (2016, figura 3) }\end{array}$ \\
\hline $\begin{array}{l}1^{\circ} \text { - Camada arenosa com pequenos seixos, } \\
\text { fragmentos de quartzo e fragmentos de arenito, } \\
\text { apoiada na base rochosa }\end{array}$ & $\begin{array}{c}24.000 \\
a \\
29.000 \mathrm{cal} \mathrm{AP}\end{array}$ & $\begin{array}{l}\text { Unidade C - Melo (2007, p. 309) } \\
\text { III - Aimola et al. (2014, figura 4) } \\
\text { Lower unit - Boëda et al. (2016, figura 3) }\end{array}$ \\
\hline
\end{tabular}

\footnotetext{
2 Seguindo os trabalhos da Comissão Internacional de Estratigrafia (do inglês International Commission on Stratigraphy - ICS), considera-se aqui como data convencional do final do Pleistoceno aquela de 11.700 anos antes do presente (em idade calibrada) (Walker et al., 2009).

Vinte e seis datas entre $7.240 \pm 45$ e $14.300 \pm 400$ AP não calibrado (Melo, 2007).

4 Cinco datas entre $20.280 \pm 450$ e $25.170 \pm 140$ AP não calibrado (Melo, 2007; Boëda et al., 2016).
}

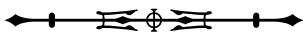


Figura 3. Nas camadas datadas entre 17.500 e $15.000 \mathrm{cal}$ $\mathrm{AP}^{5}$, foi encontrada uma centena de peças líticas lascadas de origem antrópica (Aimola et al., 2014).

O sítio a céu aberto Vale da Pedra Furada está localizado nas proximidades do abrigo Pedra Furada
(Felice, 2002; Boëda et al., 2014a). Apresenta uma sequência estratigráfica com alternância de camadas arenosas (C8, C6, C4, C2) e de camadas com clastos (seixos rolados e placas de arenito) (C7, C5, C3) (Boëda et al., 2014a). A camada C3, datada entre

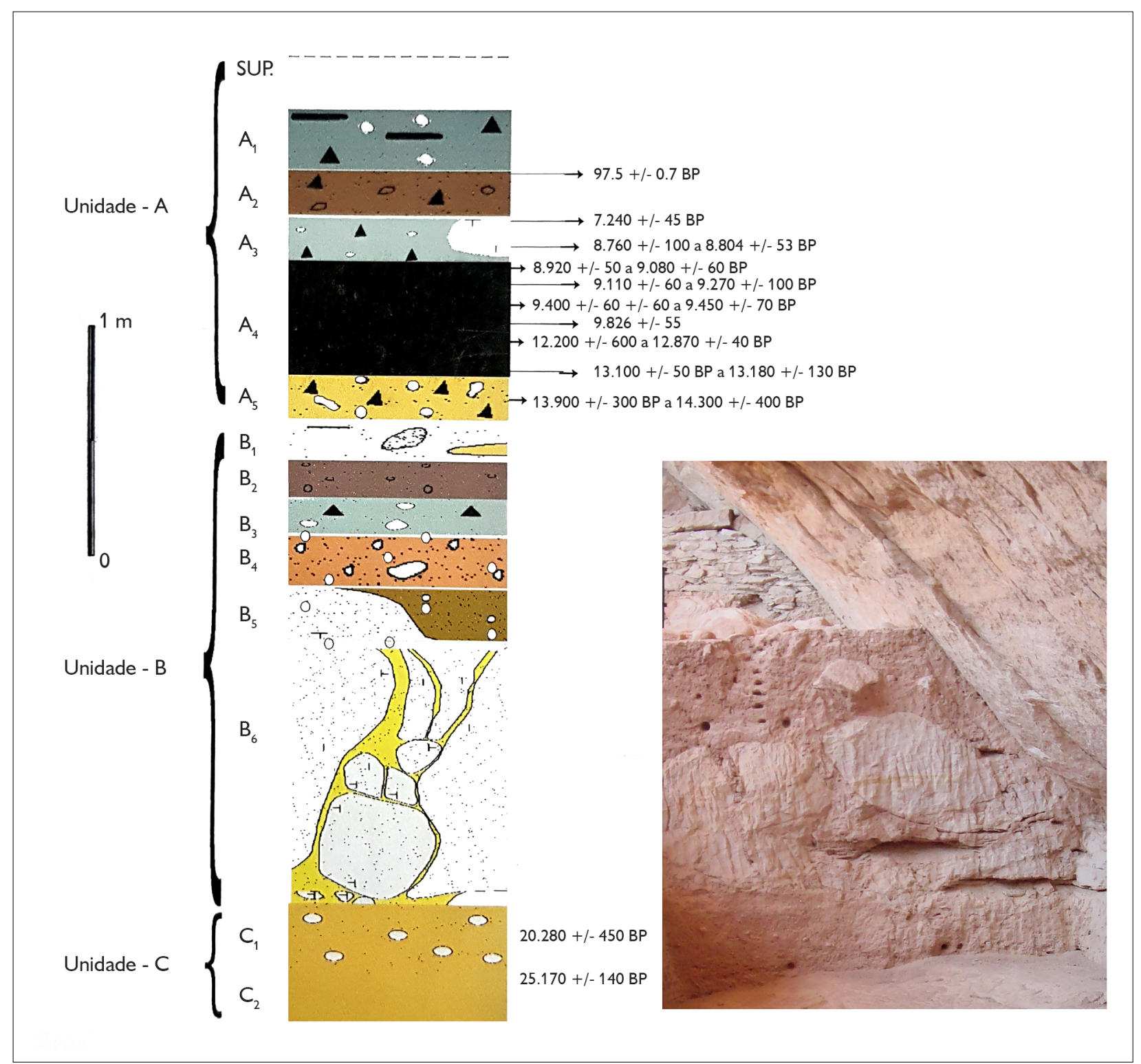

Figura 3. Sítio do Meio. Sequência estratigráfica sintética da parte interna do abrigo e datações radiocarbônicas não calibradas referentes a cada camada. Fonte: Melo (2007, p. 309).

5 Entre $12.640 \pm 120$ e $14.300 \pm 400$ AP não calibrado.

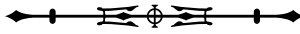


19.500 e 15.000 cal AP6 , é composta de quatro níveis de clastos maiores, todos com material lítico (C3a, b, c, d), totalizando 150 peças lascadas antrópicas, algumas delas com microtraços de uso.

No sítio Tira-Peia, no maciço calcário do Antero, outros indícios de presença humana desse período foram publicados (Lahaye et al., 2013; Boëda et al., 2014c). A homogeneidade textural e colorimétrica do sedimento dificultou o reconhecimento de diferentes camadas, mas a disposição do material lítico lascado evidenciou vários momentos de deposição, confirmados por remontagens e pela distribuição das datas por Luminescência Opticamente Estimulada (LOE). O nível mais rico em vestígios líticos (C6), com 57 peças, foi datado de 17.100 AP7 (Lahaye et al., 2013; Boëda et al., 2014c).

Finalmente, no que diz respeito à faixa de tempo entre 18.000 e $14.000 \mathrm{cal}$ AP, encontram-se, na bibliografia, referências relativas ao sítio Garrincho. Trata-se de uma caverna cárstica com preenchimentos sedimentares holocênico e pleistocênico, separados por um assoalho estalagmítico, datado em 11.500 cal AP8 por carvões presos na concreção (Peyre et al., 1998). Escavações no interior da caverna realizadas entre 1990 e 1992 evidenciaram, abaixo do espeleotema, ossos de fauna fóssil mineralizados e dois dentes humanos (Guidon et al., 2000). Foi obtida uma data

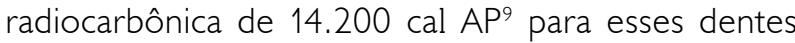
a partir do carbono dos ácidos da lavagem de prétratamento (com o colágeno sendo insuficiente para uma datação direta).

Antes da intervenção arqueológica, em 1986, o proprietário do sítio tinha aberto uma cisterna na entrada da caverna, zona na qual o assoalho estalagmítico não era presente. $\mathrm{Na}$ vistoria do sedimento retirado, foram encontrados fauna atual não fossilizada, fauna fóssil

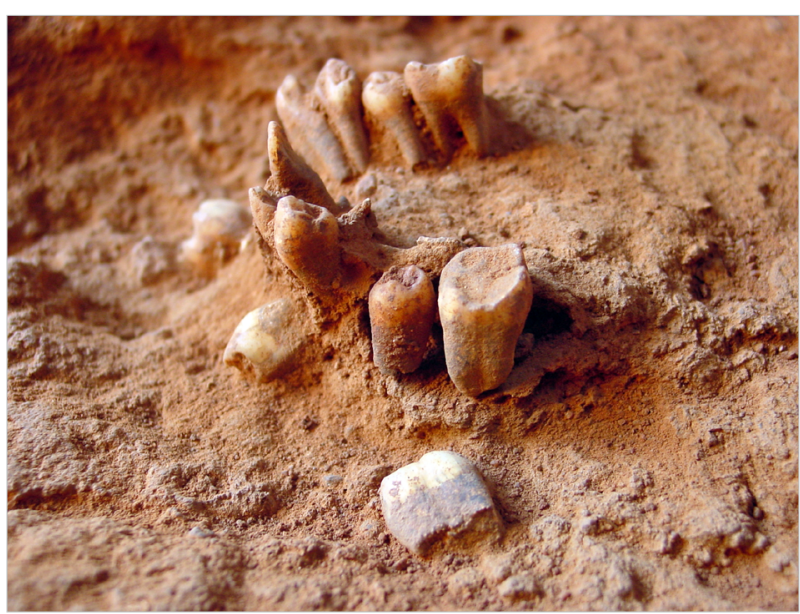

Figura 4. Garrincho. Conjunto de dentes de criança. Direção: Gisele Daltrini Felice. Fonte: Arquivos da Fundação Museu do Homem Americano (FUMDHAM) (2003).

mineralizada, 12 peças líticas lascadas e um parietal humano (Peyre et al., 1998; Guidon et al., 2000). O forte grau de mineralização do parietal fez com que ele fosse associado ao conjunto pleistocênico do interior da caverna. Essa foi uma atribuição cronológica coerente, segundo os autores, com o aspecto arcaico desse osso (Peyre et al., 1998).

No início dos anos 2000, outros conjuntos de restos humanos foram encontrados na parte externa do sítio, em dois pequenos abrigos ao lado da entrada da caverna: um conjunto de 29 dentes de criança a $75 \mathrm{~cm}$ de profundidade (Figura 4), junto com artefatos líticos, e um fragmento de crânio a 1,10 m de profundidade, associado a um raspador de sílex (Felice, 2006; Peyre et al., 2009). O sedimento de onde provém o fragmento de crânio foi datado em $14.100 \pm 1.800$ AP por termoluminescência e $24.000 \pm 3.000$ AP por LOE (Santos, J. et al., 2005; Felice, 2006). A idade recuada desses restos também se encontra corroborada, segundo Peyre et al. (2009), pelas suas morfologias arcaicas.

\footnotetext{
6 Três datas por 14C entre $12.700 \pm 90$ e $13.740 \pm 60$ AP não calibradas; $17.500 \pm 2.000$ BC por LOE (Boëda et al., 2014a).

$15.100 \pm 1.200 \mathrm{BC}$ por LOE (Lahaye et al., 2013).

10.020 \pm 290 AP não calibrado (Peyre et al., 1998).

$912.170 \pm 40$ AP não calibrado (Guidon et al., 2000).
}

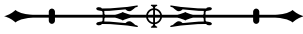


Em síntese, cinco restos humanos ou conjuntos de restos provêm de Garrincho, três deles sendo associados a três datações absolutas do Pleistoceno final. No entanto, cabe salientar as incertezas da data radiocarbônica de 14.200 cal AP, uma vez que as medidas provêm do carbono dos ácidos da lavagem de pré-tratamento (Taylor, 1987). Quanto às duas outras datas, por Luminescência Opticamente Estimulada (LOE) e Termoluminescência $(T L)$, elas foram divulgadas em um curto trabalho inédito (Santos, J. et al., 2005), sem apresentar a maioria dos parâmetros experimentais utilizados, nem as medidas de fading, e sem mencionar os limites da datação por TL de sedimento não aquecidos (Mercier, 2008). Tal lacuna não permite avaliar a fiabilidade dessas datas.

Em conclusão, os restos humanos de Garrincho apresentam um bom potencial de serem antigos, provavelmente plenamente pleistocênicos, em particular os dois dentes encontrados dentro da caverna, abaixo do assoalho estalagmítico. No entanto, até o momento, infelizmente, essas atribuições cronológicas permanecem não totalmente conclusivas.

\section{UMA PRESENÇA HUMANA ANTECEDENDO O ÚLTIMO MÁXIMO GLACIAL}

Os modelos propondo o Último Máximo Glacial (UMG) (aproximadamente 20.000 AP) como limite inferior para a chegada do homem nas Américas, que tendem a predominar atualmente na bibliografia, não contemplam a totalidade do registro arqueológico existente no continente. Indícios de uma presença humana mais remota existem tanto na América do Norte (Bourgeon et al., 2017; Lowery et al., 2010) quanto na América do Sul (Vialou et al., 2017).

A área da Serra da Capivara contém a maior concentração de sítios americanos pré-UMG conhecidos até hoje, como o Pedra Furada, o Sítio do Meio, o Vale da Pedra Furada, o Tira-Peia e, possivelmente, a caverna das Moendas.
Pedra Furada é o mais famoso dos sítios pleistocênicos da região, por ser objeto de publicações há 40 anos e ter proporcionado as datas mais antigas (Guidon; Delibrias, 1986), sendo que uma síntese e dados mais recentes da escavação foram publicados em Parenti (2001). Esse abrigo foi estudado de 1978 a 1988 em uma superfície total de $400 \mathrm{~m}^{2}$ e uma profundidade de mais de 4 m (Figura 5). O preenchimento sedimentar é principalmente pleistocênico. A cobertura holocênica tem menos de $1 \mathrm{~m}$ de espessura. Dada a descontinuidade das camadas à escala do abrigo, a estratigrafia arqueológica foi estabelecida a partir da cronologia relativa (sobreposições e proximidades) e absoluta (datas radiocarbônicas) das estruturas distribuídas ao longo da sequência. Trata-se de estruturas de combustão e de concentrações de pedras (Parenti, 2001). Para o Pleistoceno, foram determinados três conjuntos cronoestratigráficos, chamados de fases Pedra Furada 1, 2 e 3 (PF1, PF2, PF3). A fase PF1 foi datada de aproximadamente 50.000 a 35.000 anos AP não calibrados ${ }^{10}$. Ela compõe-se de 13 estruturas de combustão e quatro concentrações de pedra, além de 125 vestígios líticos lascados. Na fase PF2,

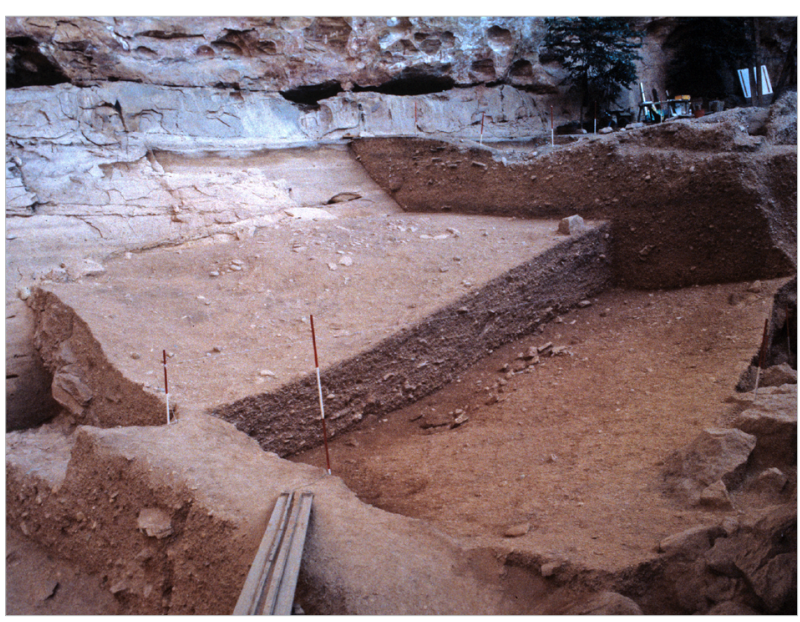

Figura 5. Pedra Furada. Escavação dos níveis pleistocênicos. Direção: Fabio Parenti. Fonte: Arquivos da Fundação Museu do Homem Americano (FUMDHAM) (1988).

\footnotetext{
10 Treze datas entre $>50.000$ e $>35.000$ AP não calibrado (Parenti, 2001, p. 100).
}

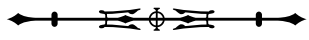


entre 36.300 e 29.000 cal AP ${ }^{11}, 30$ estruturas de combustão, 18 concentrações de pedras e 176 peças de pedra lascada foram coletadas. Por sua vez, a fase PF3, que data de 25.500 a 20.500 cal AP', contém oito estruturas de combustão, nove concentrações de pedras e 89 artefatos líticos lascados.

Datações por termoluminescência foram realizadas em 39 blocos das estruturas de combustão (29 de PF1, dez de PF2), com objetivo de determinar a idade da queima dos mesmos (Michab, 1999; Valladas et al., 2003). Os resultados deram datas entre 147.000 e 33.000 AP. A metade das datas TL dos blocos de PF2 cai entre 33.000 e 43.000 AP e de cinco datas de PF1, entre 63.000 e 45.000 AP. Apesar de mais antigas, essas idades condizem, de modo geral, com as datas radiocarbônicas. Os outros resultados distribuem-se entre 85.000 e 50.000 AP para PF2 (cinco datas) e entre 147.000 e 69.000 AP para PF1 (24 datas). Os autores interpretam essas discrepâncias como resultado dos limites do método radiocarbônico, a zona de confiança tendo sido atingida ou ultrapassada para uma parte das amostras entre 50.000 e 30.000 anos $^{13}$. Isso implica o fato de as idades verdadeiras de PF1 e PF2 serem possivelmente mais antigas do que sugerido pelos resultados por $14 \mathrm{C}$. No entanto, os autores salientam que não se tem elementos suficientes para propor presença humana em Pedra Furada anterior ao Estágio Isotópico 3 e que existe uma variabilidade grande das datas TL dentro dos mesmos contextos estratigráficos, a qual só poderia se explicar por perturbações tafonômicas e/ou aquecimento de origem antrópica insuficiente dos blocos para permitir 'zerar o relógio' da TL (Michab, 1999; Valladas et al., 2003).
Três sítios ocupados no intervalo entre 18.000 e 14.000 cal AP apresentam também evidências arqueológicas anteriores ao UMG.

Em Vale da Pedra Furada, a camada C5 é datada de $22.500 \mathrm{AP}^{14}$ e proporcionou 17 artefatos líticos lascados. A camada C7, mais espessa, apresentou três níveis arqueológicos, com total de 123 artefatos lascados, alguns com marcas de uso e concentrações de carvão. Os dois primeiros níveis foram datados entre 27.600 e $22.300 \mathrm{cal}$ AP $^{15}$ (Boëda et al., 2014a).

Em Sítio do Meio, na camada arenosa, entre a base rochosa do interior do abrigo e o espesso nível de desabamento, datada entre 29.000 e $24.000 \mathrm{cal} \mathrm{AP}$ (Quadro 1), encontrou-se mais de 1.500 artefatos líticos, alguns com marcas de uso, assim como um alinhamento de blocos de arenito delimitando uma concentração de peças lascadas (Boëda et al., 2016).

Em Tira-Peia, a camada C7 continha seis artefatos lascados e foi datada por LOE ao redor de $22.000 \mathrm{AP}^{16}$. Abaixo dessa camada, 13 peças líticas lascadas foram descobertas na C8 e duas na C9 (Lahaye et al., 2013; Boëda et al., 2014c).

Um último sítio poderia testemunhar uma ocupação pré-UMG na região. Trata-se de Moendas, um sumidouro que formou uma ampla caverna cárstica no maciço calcário de mesmo nome, integralmente fechada por sedimentos e blocos caídos no início da escavação. Encontraram-se numerosos restos de megafauna pleistocênica, vestígios arqueológicos e três esqueletos humanos incompletos (Guidon et al., 2009). O esqueleto 3 compõe-se de fragmentos de ossos cranianos e de membros de um indivíduo

11 Quatorze datas entre $32.160 \pm 1.000$ e $\geq 25.000$ AP não calibrado (Parenti, 2001, p. 99).

12 Quatro datas entre $21.400 \pm 400$ e $17.000 \pm 400$ AP não calibrado. Existe também uma data de $14.300 \pm 210$ AP não calibrado (Parenti, 2001, p. 99).

13 Tal interpretação encontra-se corroborada pela existência, para as fases PF1 e PF2, de sete datas radiocabônicas 'não finitas': > 35.000, $>39.200,>42.600, \geq 45.000, \geq 47.000,>48.000$ e > 50.000 AP (Parenti, 2001, p. 100).

$1420.600 \pm 2.400$ BC por LOE (Boëda et al., 2014a).

15 Cinco datas por 14C entre $20.090 \pm 120$ e $18.660 \pm 260$ AP não calibradas; quatro datas por LOE entre $25.600 \pm 2.600$ e 21.400 \pm 2.800 BC (Boëda et al., 2014a).

$1620.000 \pm 1.500 \mathrm{BC}$ por LOE (Lahaye et al., 2013).

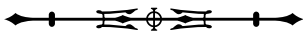


masculino adulto (Almeida; Neves, 2009). Dois dentes de cervídeo (Blastocerus dichotomus), achados à proximidade desses restos humanos, foram datados por Ressonância Paramagnética Eletrônica (do inglês Electron Paramagnetic Resonance - EPR) de $29.000 \pm 3.000$ e $24.000 \pm 1.000$ AP, e a camada concrecionada, que cobre a estratigrafia nesse lugar, possui datas por LOE de $46.000 \pm 1.500$ e 21.000 \pm 3.000 AP (Kinoshita et al., 2014)17. Os autores concluem que o esqueleto humano tem a mesma antiguidade que os dentes de cervídeo. No entanto, dada a complexidade dos processos de sedimentação nesse sítio, estudos tafonômicos e geoarqueológicos complementares seriam necessários para corroborar essa associação estratigráica.

Como no resto do continente, esses sítios préUMG são alvo das críticas mais exacerbadas. Nas sínteses continentais, os sítios da Serra da Capivara são, na maioria dos casos, simplesmente ignorados. Sendo o mais antigamente publicado, Pedra Furada é o sítio mais comentado da região ${ }^{18}$. Mais recentemente, as discussões também incluíram Vale da Pedra Furada e Tira-Peia (Dias; Bueno, 2014; Borrero, 2015). De forma clássica, os questionamentos são relativos à fiabilidade das evidências arqueológicas, à qualidade das datações e à associação indiscutível dessas duas categorias de dados, principalmente acessível via uma abordagem tafonômica refinada. Os pesquisadores responsáveis pelas escavações desses sítios responderam a essas críticas trazendo informações e dados complementares (Guidon; Pessis, 1996; Parenti et al., 1996; Boëda et al., 2014a). Outras críticas dizem respeito a considerações extrínsecas aos dados arqueológicos dos sítios em si, como o fato de as ocupações humanas sugeridas para esses sítios serem difíceis de integrar os modelos de povoamento do continente (Dias; Bueno, 2014) ou, ainda, a opinião surpreendente de que é duvidoso que o Homo sapiens tenha-se confinado a uma arcaica produção sobre seixos (Borrero, 2015, 2016). Tais observações sugerem que a aceitação ou não desses indícios antigos de presença humana não seja ligada somente às propriedades intrínsecas dos sítios, mas também a representações 'a priori' do que deveria ser um sítio antigo na América do Sul.

A queda do modelo Clovis first deixou espaço para uma reorganização da maneira de pensar os povoamentos americanos na pré-história. A hipótese predominante atualmente, a de um povoamento préClovis, mas pós-UMG - idade induzida pelos estudos genéticos (Raghavan et al., 2015), via a costa pacífica (Braje et al., 2017) -, também apresenta limites ligados, por exemplo, ao contexto geológico. As possibilidades de serem encontrados testemunhos arqueológicos em quantidade no litoral são limitadas, devido à transgressão pós-glaciária. Existe também uma representação, talvez exagerada, quanto à barreira do inlândsis norteamericano (Bélanger et al., 2014). Quanto ao fato de arqueólogos usarem as datas absolutas oriundas dos estudos genéticos para defenderem suas hipóteses, é preciso alertar sobre o perigo do raciocínio circular desse procedimento, pois os geneticistas usam marcadores arqueológicos e paleontológicos para a calibração de seus dados cronológicos, não sendo satisfatória em si a exatidão do relógio molecular (Lee; Ho, 2016). Em vez de cristalizar os estudos do povoamento americano de novo em um modelo fechado, uma outra atitude dos pesquisadores poderia ser de deixar as interpretações em aberto, considerando a viabilidade de várias hipóteses.

Nossa posição aqui é de considerar como válidas as ocupações pleistocênicas atestadas pelos sítios da Serra da Capivara. Como apresentado anteriormente, subsistem dúvidas quanto a alguns casos. As datas mais antigas, ao redor de 100.000 anos, não apresentam, por enquanto, fiabilidade

\footnotetext{
17 Outra data de 13.000 AP por EPR para essa camada concrecionada superior é mencionada em Guidon et al. (2009), mas ignorada em Kinoshita et al. (2014).

18 Por exemplo, por Meltzer et al. (1994).
}

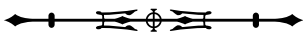


suficiente para serem levadas em consideração. Outrossim, por ser a única manifestação tão antiga na região, a fase PF1 de Pedra Furada (entre 50.000 e 35.000 anos) precisaria ser documentada mais em detalhe. Mas, a partir de cerca de 30.000 anos, existe inegável convergência de dados consolidados em diferentes sítios e diferentes ambientes da região para apoiar presença humana pleistocênica. Junto com outros sítios, como Santa Elina, no Mato Grosso (Vialou et al., 2017), esses dados apontam para presença humana no continente desde pelo menos o final do estágio isotópico 3. Tal passado longo da pré-história americana condiz com a originalidade de culturas autóctones, como a de Clóvis, e a variabilidade muito pronunciada das manifestações humanas desde a transição Pleistoceno-Holoceno em todo o continente. No estado atual da pesquisa, a escassez de dados desse período remoto na escala continental não permite mais do que conjecturas quanto aos processos de povoamento, abrindo infinitas possibilidades. Reduzi-las dentro de modelos poderia abrir um leque de propostas interessantes, mas não deve nos fazer esquecer o quanto não sabemos ainda desse longo e complexo processo.

\section{QUEM SÃO? OS RESTOS ESQUELETAIS}

\section{VESTÍGIOS PALEOANTROPOLÓGICOS ANTIGOS ENCONTRADOS NA SERRA DA CAPIVARA}

Os vestígios ósseos humanos encontrados nos sítios arqueológicos da Serra da Capivara foram objeto de uma síntese recente (Strauss et al., 2018). Para o período que nos interessa aqui, referem-se a restos esqueletais localizados nos seguintes sítios: Cerca do Elias, Paraguaio, Coqueiros, Antonião, Garrincho e Moendas. Mencionamse em outras fontes vestígios humanos em Boa Vista II (Guidon, 1981) e Sítio do Meio (Melo, 2007).

Nenhum resto humano foi encontrado até hoje para os primeiros momentos de ocupação da região. A validação da datação do esqueleto 3 das Moendas fica condicionada a um melhor conhecimento do contexto de deposição e dos processos pós-deposicionais. Os restos do Garrincho (fragmentos de duas calotas, uma série de dentes, conforme a Figura 4 - e dois dentes isolados) apresentam uma convergência de probabilidades quanto a uma data do final do Pleistoceno. A análise desses vestígios evidenciou traços interpretados como arcaicos: importante espessura dos fragmentos cranianos, grande formato e forte achatamento dos dentes (Peyre et al., 1998, 2009).

Para a transição Pleistoceno-Holoceno e para o Holoceno inicial, os dados são mais numerosos. Restos humanos associados a esse período foram encontrados em seis sítios arqueológicos da Serra da Capivara (Figura 6). As principais características desses achados encontram-se resumidas no Quadro 2.

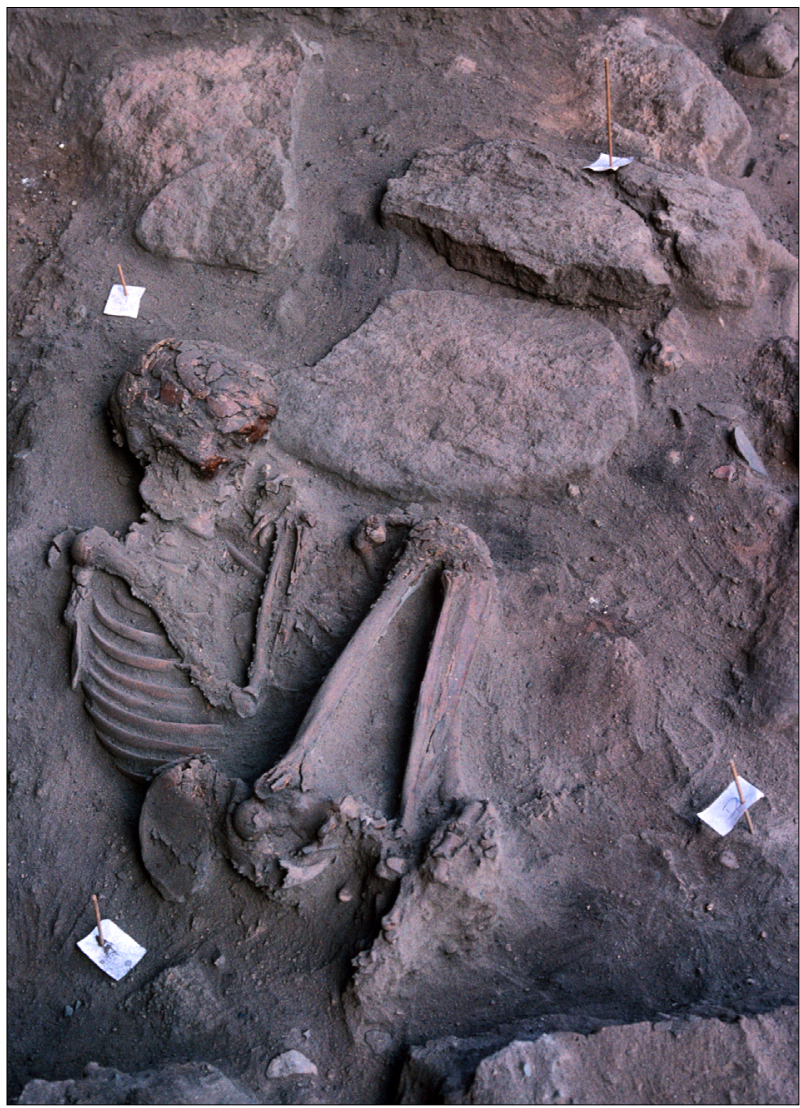

Figura 6. Coqueiros. Sepultamento primário de adulto datado da transição Pleistoceno-Holoceno. Direção: Niède Guidon. Fonte: Arquivos da Fundação Museu do Homem Americano (FUMDHAM) (1997)

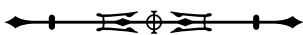


Quadro 2. Síntese dos restos humanos associados a datas da transição Pleistoceno-Holoceno e do Holoceno inicial encontrados na Serra da Capivara.

\begin{tabular}{|c|c|c|c|c|}
\hline Sítio arqueológico & Restos encontrados & Data & Elemento datado & Fonte bibliográfica \\
\hline Cerca do Elias & $\begin{array}{l}\text { Dentes e fragmentos } \\
\text { de crânio (NMI: 2) }\end{array}$ & $\begin{array}{l}{[12.050-11.770]} \\
\text { cal AP }^{19}\end{array}$ & $\begin{array}{l}\text { Carvão a } 70 \text { cm, na mesma } \\
\text { estrutura de combustão, no } \\
\text { principal nível arqueológico }\end{array}$ & $\begin{array}{l}\text { Guidon et al. (2009); } \\
\text { Lourdeau e Pagli (2014); } \\
\text { Strauss et al. (2018) }\end{array}$ \\
\hline Coqueiros & $\begin{array}{l}1 \text { esqueleto de } \\
\text { adulto }^{20}\end{array}$ & $\begin{array}{c}{[11.390-11.170]} \\
\mathrm{cal} \mathrm{AP}^{21}\end{array}$ & $\begin{array}{l}\text { Carvão incrustrado no calcâneo, } \\
\text { dentro da estrutura funerária }\end{array}$ & Guidon et al. (1998) \\
\hline Antonião & $\begin{array}{l}1 \text { esqueleto de mulher } \\
\text { adulta }^{22}\end{array}$ & $\begin{array}{l}{[11.290-10.560]} \\
\text { cal AP }^{23}\end{array}$ & $\begin{array}{l}\text { Carvões }{ }^{24} \text { dentro da mesma } \\
\text { estrutura de combustão }\end{array}$ & Peyre (1994) \\
\hline Boa Vista II & Ossos & $\begin{array}{l}{[11.270-10.610]} \\
\quad \mathrm{cal} \mathrm{AP}^{25}\end{array}$ & Carvão associado com os ossos & $\begin{array}{l}\text { Guidon (1981); } \\
\text { Arnaud et al. (1984) }\end{array}$ \\
\hline Sítio do Meio & Dentes de criança & $\begin{array}{c}{[10.190-9.770] \mathrm{cal}} \\
\mathrm{AP}^{26}\end{array}$ & $\begin{array}{c}\text { Carvão dentro da estrutura } \\
\text { funerária }\end{array}$ & Melo (2007) \\
\hline Paraguaio & $\begin{array}{l}1 \text { esqueleto de mulher } \\
\text { adulta ('sepultura } 2 \text { ') }{ }^{27}\end{array}$ & $\begin{array}{c}{[10.150-9.430] \mathrm{cal}} \\
\mathrm{AP}^{28}\end{array}$ & $\begin{array}{l}\text { Carvão dentro da estrutura } \\
\text { funerária }\end{array}$ & Alvim e Ferreira (1985) \\
\hline
\end{tabular}

Apesar de várias tentativas, nenhuma datação absoluta foi obtida diretamente a partir dos ossos, por falta de preservação do colágeno (Strauss et al., 2018). No entanto, na maioria dos casos, as informações publicadas quanto ao contexto estratigráfico dos restos permitem apoiar essas idades da transição Pleistoceno-Holoceno e do Holoceno antigo. A datação sempre foi obtida a partir de um carvão encontrado contra os ossos ou a uma distância de até algumas dezenas de centímetros. Mas em todos os casos, esse carvão provinha de uma estrutura de combustão associada aos vestígios ósseos ou fazendo parte da estrutura funerária.

Um ponto fraco dessas determinações cronológicas, no entanto, é a existência de uma única data associada a cada resto ou conjunto de resto. Isso não permite controlar a eventualidade de datas aberrantes decorrentes da intrusão de carvão mais antigo. Contudo, a repetição das datas dentro de uma faixa de tempo relativamente restrita, no início do Holoceno, dá uma coerência a esse conjunto de dados.

$1910.270 \pm 35$ AP por radiocarbono (Guidon et al., 2009).

${ }^{20} \mathrm{O}$ sexo do esqueleto dos Coqueiros é objeto de um longo debate entre especialistas. Os restos foram atribuídos, em um primeiro tempo, a um indivíduo feminino (Lessa; Guidon, 2002). Um segundo estudo concluiu, em um indivíduo masculino grácil (Nelson, 2005), o que tendeu a ser confirmado pelas análises seguintes (Hubbe et al., 2007; Cunha, 2014).

$219.870 \pm 50$ AP por radiocarbono (Guidon et al., 1998).

22 Mais dois esqueletos e alguns ossos de um terceiro foram encontrados na escavação de outro setor do sítio. Esses restos não têm ainda atribuição cronológica (Strauss et al., 2018).

$239.670 \pm 100$ AP por radiocarbono (Peyre, 1994).

${ }^{24}$ Cinco carvões foram juntados para obter essa data (Santos, M. C., 2012, p. 43).

$259.700 \pm 120$ AP por radiocarbono (Guidon, 1981).

$268.920 \pm 50$ AP por radiocarbono (Melo, 2007)

27 Outro esqueleto, pertencendo a um indivíduo adulto masculino, foi encontrado à proximidade, associado a uma data radiocarbônica de 7.000 土 100 AP (Alvim; Ferreira, 1985; Arnaud et al., 1984). Existe uma discussão quanto a essa idade: enquanto Bernardo e Neves (2009) consideram que ela foi subestimada e que esse sepultamento teria a mesma antiguidade do outro, Strauss et al. (2018) questionam uma idade tão remota, dadas as condições de conservação excepcionais do esqueleto, ainda com presença de cabelos.

${ }^{28} 8.670 \pm 120$ AP por radiocarbono (Alvim; Ferreira, 1985).

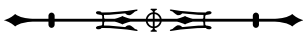


Outro elemento indicador dessa atribuição cronológica: os vestígios líticos associados aos contextos arqueológicos desses ossos humanos podem ser atribuídos, na maioria dos casos, ao Tecnocomplexo Itaparica, conhecido no Centro e no Nordeste do Brasil durante a transição Pleistoceno-Holoceno e o Holoceno inicial (Lourdeau, 2015).

Encontra-se, então, na Serra da Capivara, uma das maiores concentrações existentes no continente de vestígios humanos datados entre 12.000 e 9.500 cal AP, com três esqueletos semicompletos (quatro, se considerarmos o sepultamento 1 do Paraguaio) e um número mínimo total de sete a oito indivíduos ${ }^{29}$.

\section{CONTRIBUIÇÃO DESSES RESTOS EM CONSIDERAÇÕES EXTRARREGIONAIS}

Existem debates quanto aos processos de migração de populações ao longo da pré-história antiga das Américas, antes da chegada das populações do extremo Norte, provavelmente mais recente. São numerosas as hipóteses formuladas nas publicações (Schmitz, K., 2004). Quanto ao número de migrações, dois modelos de povoamento tendem a polarizar as discussões. Segundo uma parte dos especialistas, ocorreram duas levas de povoamento sucessivas entre o final do Pleistoceno e o Holoceno médio, com substancial troca de população. Outra parte defende um único momento de chegada, ocorrida na época da colonização inicial do continente.

A primeira hipótese é sustentada por estudos morfológicos dos crânios pré-históricos. Existe uma diferença entre os restos da transição Pleistoceno-Holoceno e do Holoceno inicial e os restos a partir do Holoceno médio, esses últimos sendo morfologicamente semelhantes aos das populações ameríndias atuais (Hubbe et al., 2010).
Alguns dos restos da Serra da Capivara foram incluídos nessas análises craniométricas: os de Coqueiros (Figura 6), os dois esqueletos de Paraguaio e dois outros sítios do Holoceno recente (Hubbe et al., 2007; Bernardo; Neves, 2009). As medidas dos crânios de Coqueiros e de Paraguaio 1 condizem com a morfologia dos restos do Holoceno inicial das demais partes do continente, mas as de Paraguaio 2 correspondem ao conjunto recente. Os autores explicam as diferenças entre os dois crânios de Paraguaio pelo fato de eles datarem do período de transição entre uma morfologia e a outra, o que corresponderia ao momento da substituição populacional, ao redor de 8.500 AP (Bernardo; Neves, 2009).

Os dados genéticos apontam, no entanto, para um único grande momento de entrada no continente durante a pré-história. Evidenciada a partir do estudo genético das populações autóctones atuais (Zegura et al., 2004; Fagundes et al., 2008), essa posição foi confirmada pelas recentes análises genômicas de restos antigos (Rasmussen et al., 2015; Raghavan et al., 2015). A hipótese de uma única leva principal de povoamento, seguida por uma diversificação interna das populações, encontra-se também sustentada por dados morfológicos, em recente estudo usando a morfometria geométrica 3D (Galland, 2013; Galland; Friess, 2016).

Devido à ausência de DNA preservado, nenhum resto do Holoceno inicial da Serra da Capivara contribuiu para os estudos genéticos ${ }^{30}$. No entanto, o crânio de Coqueiros foi utilizado nessa última pesquisa craniométrica (Galland, 2013).

\section{SEQUÊNCIA ARQUEOLÓGICA DA SERRA DA CAPIVARA: OS COMPORTAMENTOS HUMANOS NO TEMPO LONGO}

Se os indícios de presença humana anteriores a 8.000 anos ficam, ao todo, relativamente discretos na Serra da

${ }^{29}$ Com exceção do indivíduo de Lapa Vermelha IV ('Luzia'), datado da transição Pleistoceno-Holoceno (Feathers et al., 2010; Fontugne, 2013), os restos humanos da região de Lagoa Santa datam de depois de 9.500 anos AP não calibrados (Hubbe; Neves, 2016), sendo, então, mais recentes do que os remanescentes da Serra da Capivara aqui apresentados, com exceção do Sítio do Meio e do Paraguaio.

30 Foi sequenciado o DNA do indivíduo Enoque65 da Toca do Enoque, situada nas proximidades da Serra da Capivara, datado diretamente por radiocarbono em $3.335 \pm 20$ AP, ou seja, [3.640-3.480] cal AP (Raghavan et al., 2015). 
Capivara quanto aos restos esqueletais, eles se apresentam, ao contrário, de forma exuberante pelas manifestações culturais encontradas nas pesquisas arqueológicas.

\section{O PLEISTOCENO}

\section{Tecnologia lítica}

Como mencionado, os vestígios líticos dos sítios pleistocênicos da Serra da Capivara ainda são alvos de discussões (Meltzer et al., 1994; Fiedel, 2017). A questão é de determinar se se trata de fragmentos naturais ou de artefatos antrópicos. Duas abordagens foram utilizadas para demonstrar a mão do homem nesses objetos. Parenti (2001) e Parenti et al. (2018) comparam os vestígios de Pedra Furada com objetos encontrados em pontos de forte fragmentação natural das pedras, ao pé de cachoeiras intermitentes, nos arredores do abrigo. A observação de critérios como a quantidade de negativos de retiradas e a posição dos mesmos evidenciou uma clara diferença entre os conjuntos naturais e os vestígios de Pedra Furada. Em uma perspectiva qualitativa, Boëda (2014) e Boëda et al. (2014b, 2014c) examinaram os artefatos líticos dos sítios pleistocênicos da Serra da Capivara, tentando entender a lógica, caso tivesse, das retiradas, observando sua ordem, posição e consequência na superfície dos objetos. Este estudo baseia-se no princípio segundo o qual a natureza, seja ela por fatores gravitacionais (queda do paredão) ou animais (fraturamentos de pedras, intencionais ou não ${ }^{31}$ ), não lasca a pedra, e sim a quebra: não há coerência na dinâmica técnica nem na organização das retiradas efetuadas na superfície de um bloco. A maioria dos objetos oriundos dos sítios apresenta uma lógica das sequências de lascamento interpretável em termos de claras intenções técnicas, como o façonnage ou a debitagem de suportes, com objetivo de obter determinadas estruturas volumétricas, ou, ainda, a obtenção de gumes cortantes regulares e compatíveis com atividades de corte. Os resultados desses estudos apontam, então, para a natureza antrópica de pelo menos parte dos artefatos pleistocênicos da região.

Os vestígios líticos dos sítios pleistocênicos da Serra da Capivara podem ser entendidos através de um elemento fundamental: os seixos. Esse tipo de suporte, usado em diferentes contextos da pré-história e de várias maneiras (Boëda, 2014), é central aqui.

Nos sítios do front de Cuesta, os seixos compõem a quase totalidade da matéria-prima utilizada durante o Pleistoceno (Parenti, 2001; Boëda et al., 2014a, 2016). De quartzo e, em proporção menor, de quartzito, eles são de origem marinha e provêm do conglomerado do topo da escarpa. No entanto, essa constância no tipo de material inicial utilizado não significa ausência de variabilidade dos esquemas operatórios, nem limitação estrita em termos de categoria de instrumentos obtidos a partir desses seixos.

Os blocos rolados foram utilizados seja como núcleos, seja como suportes de instrumentos (Figura 7). O estudo tipológico dos vestígios líticos de Pedra Furada evidenciou uma produção bastante estável ao longo do Pleistoceno (Parenti, 2001). Instrumentos são feitos sobre os seixos por algumas retiradas unifaciais ou bifaciais que produzem o gume. Podem ser divididos em diferentes grandes categorias: 'rostres'32, bicos, peças convergentes, com gume transversal, denticulados (Boëda et al., 2014b). A debitagem dos seixos permite obter lascas corticais ou semicorticais, que podem ser retocadas marginalmente. Essa debitagem pode ser realizada por percussão unipolar ou bipolar sobre bigorna. Existem diferenças na composição dos conjuntos, interpretadas em termos

${ }^{31}$ O fraturamento intencional de rochas por macacos-pregos (Sapajus libidinosus) foi recentemente observado na região. No entanto, ao contrário do que o título e o conteúdo do artigo publicado mencionam (Proffitt et al., 2016), não se trata de lascamento (flaking), e sim de quebra de pedras (breakage), já que não foi demonstrada intencionalidade técnica nessa atividade simiesca.

$32 \bigcirc$ 'rostre' é definido como "Um gume com uma parte sobressaindo da linha geral. O rostre pode ser mais ou menos saliente e de morfologia variada relacionando-se a diferentes tipos de instrumentos [...]" (Boëda et al., 2014b, p. 59).

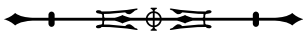


diacrônicos. A variação mais clara nesse sentido é a diminuição da proporção do trabalho bifacial a favor do trabalho unifacial ao longo do tempo, passando de quase 1 por 2, na fase PF1, a 1 por 4, na fase PF3 (Parenti, 2001). Além disso, as peças convergentes só se encontram na fase PF3 (Boëda et al., 2014b).

As grandes linhas desse sistema técnico mantêmse em Vale da Pedra Furada e Sítio do Meio, mas com especificidades em cada sítio (Boëda et al., 2014a, 2016).
Em Vale da Pedra Furada, os instrumentos sobre seixo são produzidos principalmente de maneira unifacial, sendo importante a proporção do uso da percussão bipolar sobre bigorna nas atividades de debitagem. As análises estruturais dos instrumentos demonstraram que cada tipo de objeto pode ter sido produzido somente sobre seixo, somente sobre lascas ou sobre as duas categorias de suportes. Existe uma variação na composição do instrumental a cada nível arqueológico (Boëda et al., 2014a).

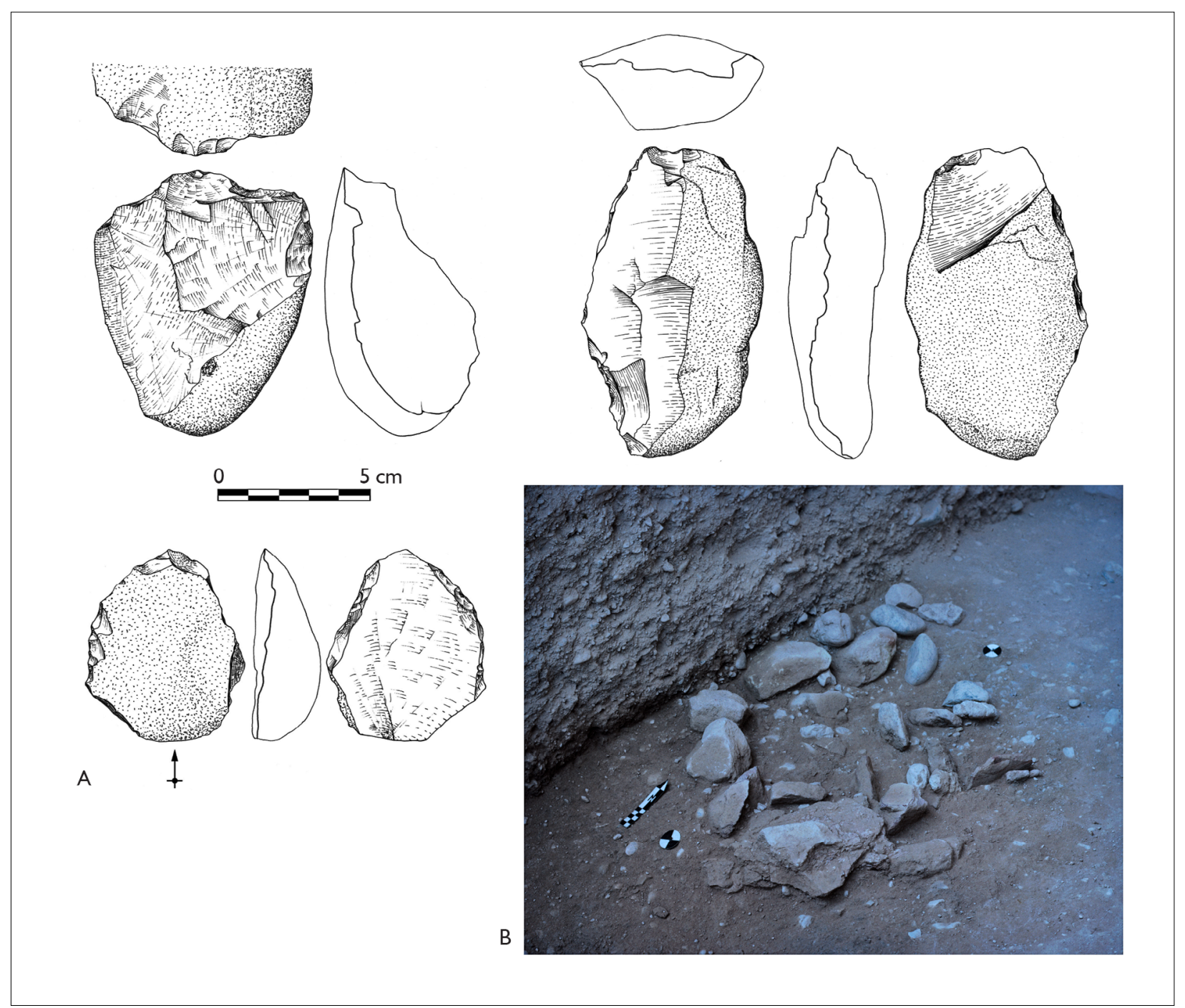

Figura 7. Pedra Furada. Artefatos pleistocênicos: (A) exemplos de peças líticas; (B) estrutura de combustão cercada de pedras, associada à fase PF2. Direção: F. Parenti. Fontes: Lourdeau e Pagli (2014, p. 603) (A); Arquivos da Fundação Museu do Homem Americano (FUMDHAM) (1988) (B).

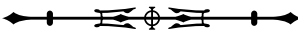


Em Sítio do Meio, a densidade de vestígios lascados é mais importante do que nos dois anteriores, com mais de 1.500 peças líticas encontradas em $4 \mathrm{~m}^{2}$ (Boëda et al., 2016). Somente $5 \%$ delas são de quartzito, matéria-prima sempre usada para a produção de grandes instrumentos. A maioria do conjunto compõe-se de lascas e de pequenos seixos lascados de quartzo, quase sempre obtidos por técnica unipolar. A especificidade mais marcante desse sítio é o tamanho reduzido dos instrumentos, entre 2 e 10 $\mathrm{cm}$ para os seixos lascados e geralmente até $3 \mathrm{~cm}$ para as lascas retocadas. Os instrumentos com gume convergente predominam (Boëda et al., 2016).

Apesar da aparência 'arcaica' dessas indústrias, alegada em algumas publicações, as produções líticas pleistocênicas da Serra da Capivara não podem ser reduzidas a atividades expedientes, onde o lascamento seria ditado por necessidades imediatas de gumes cortantes, sem outras considerações. Os estudos disponíveis evidenciam um sistema técnico baseado em padrões nos modos de fazer e nos objetivos do lascamento. $O$ investimento maior encontra-se, provavelmente, na etapa de seleção da matéria-prima. Entre as variedades de quartzo disponíveis na região, aquela de melhor qualidade para o controle do lascamento foi sistematicamente preferida. As dimensões e os formatos de seixos selecionados para o lascamento correspondem também a padrões bem estabelecidos. Finalmente, a recorrência de determinadas categorias de instrumentos, com estrutura volumétrica claramente identificável, evidencia a existência de conceitos específicos (Boëda et al., 2014a, 2014b, 2016).

O sítio Tira-Peia, para o qual dispomos de descrições prévias quanto à tecnologia lítica, demostra que esse sistema técnico existe também no ambiente calcário, apesar de diferenças de matéria-prima. Nessa área, os seixos são de origem fluvial, provindo da planície de drenagem do rio Piauí. $O$ arenito silicificado é mais comum. Nos níveis do final do Pleistoceno (C6 e 7), no entanto, parece haver uma evolução das produções líticas. As matérias-primas diversificam-se com as primeiras ocorrências do uso do sílex na região, e o grau de modificação dos suportes iniciais aumenta. Surge uma verdadeira 'façonagem' dos volumes. O lascamento não se limita mais à instalação dos gumes. A quantidade reduzida do material encontrado não permite, no entanto, uma caracterização em detalhe dessa indústria (Lahaye et al., 2013; Boëda et al., 2014c).

Um momento análogo de mudança técnica ao final do Pleistoceno detecta-se também no front de Cuesta, em Sítio do Meio, nos níveis mais antigos do terceiro conjunto estratigráfico, logo acima da camada de desabamento (Quadro 1) (Aimola et al., 2014). O fundo técnico permanece similar às camadas antigas, mas aparecem novas matérias-primas, como o arenito silicificado, bem como séries de lascamento mais longas ${ }^{33}$.

\section{Organização do espaço interno dos}

sítios: as estruturas

Apesar de os níveis arqueológicos pleistocênicos da Serra da Capivara não apresentarem solos de ocupação strito sensu, é possível observar estruturas em vários deles. Elas permitem abordar a questão da organização interna desses sítios.

Em Pedra Furada, numerosas estruturas de combustão - 'fogueiras' - foram encontradas. Parenti (2001) elaborou uma tipologia delas em função da presença ou não de blocos e de sua disposição. Um total de 17 estruturas com carvão tem organização clara de blocos de arenito e de seixos de quartzo e quartzito delimitando uma área circular ou elipsoidal, alguma delas com marcas de queima nos blocos (Figura 7). Três delas apresentam-se em uma superfície levemente côncava e uma inclui blocos erguidos. Encontram-se também outras concentrações de interpretação menos evidente: 27 conjuntos de blocos esparsos associados a carvões e sete concentrações de carvão sem blocos (Parenti, 2001). Em Vale da Pedra Furada, estão também mencionadas possíveis estruturas

\footnotetext{
33 Por exemplo, ver figura 11 em Aimola et al. (2014, p. 19).
} 
de combustão nas camadas 6base, 7b e 7c (Boëda et al., 2014a). Em Sítio do Meio, pelo menos uma estrutura de combustão data do final do Pleistoceno (Melo, 2007). Outra estrutura foi descrita nos níveis mais antigos (19 unidade estratigráfica, Quadro 1). Ela delimita uma área por placas de arenito posicionadas de maneira perpendicular (em forma de L), área que continha uma grande quantidade de objetos lascados e carvões (Boëda et al., 2014c, 2016). Finalmente, existem mais de 30 concentrações de blocos sem evidência de fogo em Pedra Furada (Parenti, 2001).

As remontagens entre os objetos de pedra lascada dão também indicações quanto à organização espacial dos níveis arqueológicos. Forneceram resultados relevantes em Tira-Peia (Boëda et al., 2014c). Permitiram observar que, a cada momento de uso do sítio, foi ocupada uma área bem circundada, que muda de localização de uma camada para a outra. A quantidade reduzida de artefatos em cada camada sugere ocupações curtas. Assim, o sítio pode ser interpretado como um lugar de escalas breves, mas repetidas.

Deve-se notar, no entanto, que não foi realizada, ainda, uma abordagem espacial sintética de cada nível arqueológico pleistocênico da Serra da Capivara, juntando, por exemplo, as localizações das estruturas, aquela de cada categoria de resto lítico em função de sua matéria-prima com a das eventuais remontagens.

\section{Elementos relativos à subsistência}

Os modos de subsistência das populações pleistocênicas da região ficam amplamente desconhecidos. Nenhum resto orgânico preservou-se nos sítios publicados com ocupação pleistocênica claramente atestada, inclusive em Tira-Peia, apesar de sua localização ser em uma zona calcária, mais favorável à fossilização e à preservação dos restos faunísticos. Isso não significa que não existem restos ósseos do Pleistoceno superior na região. Mas, de forma geral, onde se tem indícios antrópicos claros não há ossos e vice-versa. Existem casos de associação estratigráfica entre restos paleontológicos e artefatos líticos em Antonião (Guérin et al., 2002; Santos, M. C., 2012; Bélo, 2012), Pena (Boëda et al., 2014b; Griggo et al., 2018) e Lagoa do Quari (Parenti et al., 2003). No entanto, essas ocorrências não são acompanhadas de datação direta do Pleistoceno ${ }^{34}$, sendo difícil avaliar a parte da ação antrópica nessas acumulações ósseas, onde a deposição natural é também atestada.
A

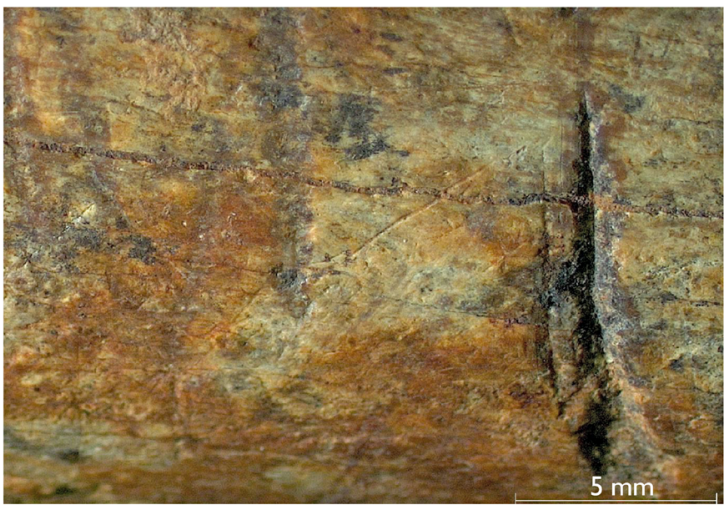

B

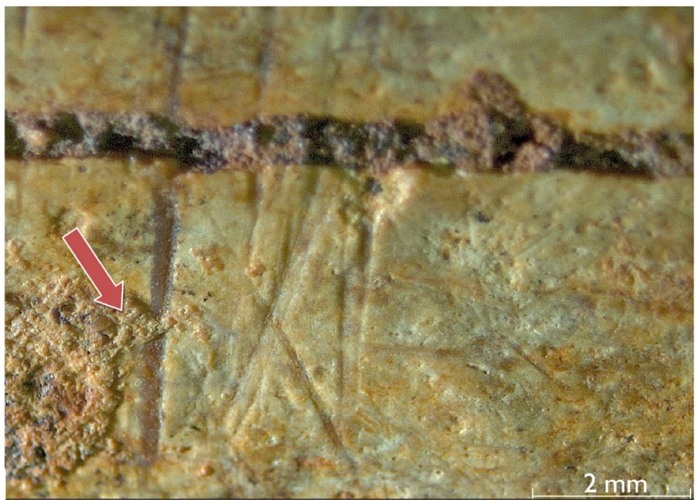

Figura 8. Antonião: (A) osso de Hippidion com marcas de corte; (B) a seta vermelha indica uma concreção cobrindo uma marca no mesmo osso. Fontes: Bélo (2012, p. 111) (A) e Bélo (2012, p. 117) (B).

34 Resultados prometedores quanto à cronologia de um setor de Antonião, com datações por LOE de até 40.000 AP para o mais profundo conjunto arqueológico, foram publicados recentemente (Lahaye et al., 2019). Espera-se a divulgação anunciada das evidências arqueológicas associadas a essas datas.

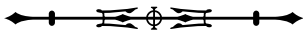


As evidências mais claras de interação entre homem e megafauna pleistocênica foram encontradas em Antonião. Os estigmas de atividades humanas antigas foram observados e descritos em 27 ossos fossilizados de fauna extinta (Bélo, 2012). Consistem em marcas de cortes e de impacto e fraturas em ossos de Paleolama, Hippidion (Figura 8), Eremotherium, Catonyx, Toxodon, Macrauchenia e Xenorhinotherium. Tais marcas podem ser relacionadas a diferentes atividades de butchering das carcaças, como remoção de tecidos, desmembramento e acesso à medula (Bélo, 2012).

Emsíntese, não há dúvidas quantoà contemporaneidade das primeiras ocupações humanas com os últimos representantes da megafauna pleistocênica. Esses últimos perduraram até o início do Holoceno, como atestado no Serrote do Artur (Faure et al., 1999). Como visto no Antonião, existiu interação e, provavelmente, consumo desses grandes mamíferos, no entanto, não se sabe ainda qual era a importância desses animais de grande porte na dieta dos grupos humanos do final do Pleistoceno, nem as técnicas de aquisição desses recursos cárneos.

A traceologia dos instrumentos líticos de Vale da Pedra Furada e do Sítio do Meio também deu elementos indiretos, podendo ser relacionados parcialmente à subsistência (Boëda et al., 2014a, 2016). Nos dois sítios, os gumes dos instrumentos foram usados sobre carne e osso, e talvez sobre couro, em Vale da Pedra Furada. As marcas de uso atestam também o trabalho da madeira. Tais ações podem não ser ligadas a atividades de subsistência, mas elas têm o mérito de nos lembrar do quanto se perdeu no que diz respeito às relações dessas populações humanas com o mundo vegetal.

\section{Contextualização macrorregional}

Dada a relativa escassez e a descontinuidade dos dados sobre as ocupações humanas do Pleistoceno na América do Sul, contrastando com a riqueza de informações ora exposta, a contextualização dos sítios da Serra da Capivara em uma escala macrorregional não é uma tarefa fácil.
Trata-se de uma concentração de evidências arqueológicas pleistocênicas ímpar no continente. O sítio que oferece as melhores possibilidades de comparação é Santa Elina, no Mato Grosso (Vialou et al., 2017). Nele, preservou-se um nível arqueológico do Pleistoceno final composto de 330 artefatos líticos, associados a restos ósseos de uma carcaça de Glossotherium. Esse nível data entre 27.000 e 25.000 AP. Os instrumentos de pedra foram principalmente feitos a partir de plaquetas de calcário, sejam elas modificadas diretamente por retoque abrupto, sejam elas debitadas em lascas a serem retocadas em seguida. Algumas pequenas plaquetas de silexito também foram retocadas. Apesar de os suportes iniciais serem diferentes, as indústrias da Serra da Capivara compartilham com aquela do nível antigo de Santa Elina o fato de se apoiarem sobre formas naturais, selecionadas por suas características volumétricas para suportarem os instrumentos, depois de modificações limitadas. Nos dois casos, essa produção é complementada por instrumentos sobre lascas oriundos de debitagem em curtas sequências, sem preparação preliminar do núcleo. A exploração de espécies de grandes mamíferos fosséis encontra-se também nos dois casos.

\section{A TRANSIÇÃO PLEISTOCENO-HOLOCENO E O HOLOCENO INICIAL}

A partir da transição Pleistoceno-Holoceno, a ocupação humana na região aumenta de maneira marcada. Baseando-se na frequência por milênio de datas por radiocarbono obtidas na Serra da Capivara, é nítido esse aumento progressivo mais rápido depois de 13.000 AP, até o oitavo e o nono milênios, com pico de maior ocorrência registrado antes de uma diminuição do número de datas no Holoceno médio (Figura 9) (Lourdeau; Pagli, 2014). Até o momento, vestígios de ocupações entre 12.700 e 8.000 AP foram encontrados em 24 sítios arqueológicos (Apêndice 1). Acumulou-se uma considerável quantidade de informações quanto a esse período. Apresentamos, a seguir, uma síntese dos principais dados relativos ao início do Holoceno na Serra da Capivara. 


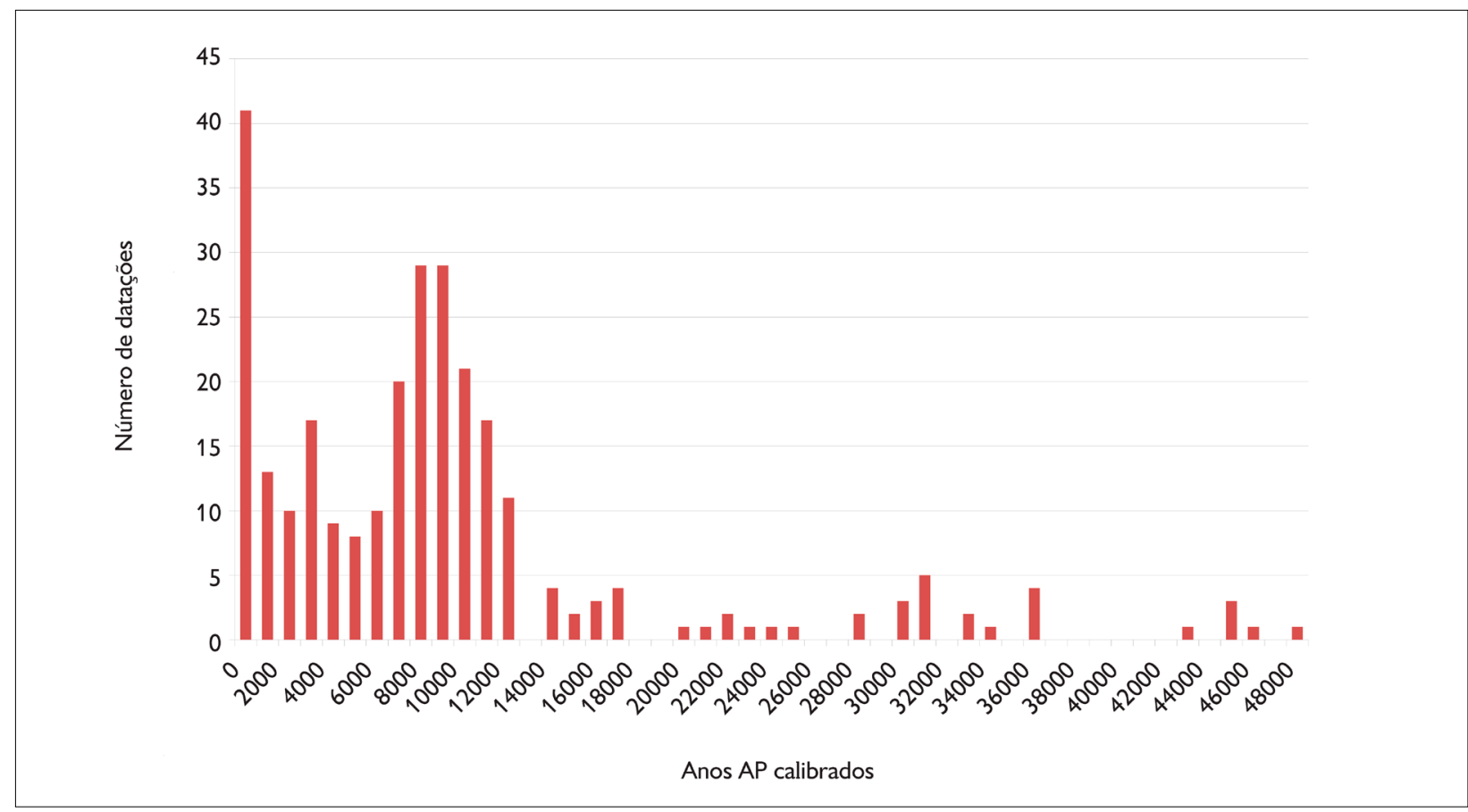

Figura 9. Distribuição cronológica das datações radiocarbônicas realizadas nos sítios arqueológicos da Serra da Capivara (em anos AP calibrados). Fonte: Lourdeau e Pagli (2014, p. 557).

\section{Características dos sítios}

Como no Pleistoceno, as implantações correspondentes a esse período distribuem-se em abrigos nos relevos ruiniformes do front de Cuesta e, com mais escassez, nos serrotes calcários do pedimento. A densificação da ocupação do front de Cuesta aparece de maneira nítida, com uma intensificação da presença humana longe, no interior dos vales secundários (no Desfiladeiro da Capivara, no Baixão da Pedra Furada, no Baixão do Perna, entre outros). Os vales do revés da Cuesta que dissecam a chapada em sentido sul-norte estão também ocupados. É o caso, em particular, da Serra Branca, na parte oeste da região, que concentra um quarto dos abrigos da transição Pleistoceno-Holoceno e do Holoceno inicial. A colonização dessas novas zonas pode ser interpretada como uma expansão territorial das populações préhistóricas da Serra da Capivara. Porém, é importante ponderar essa interpretação pelo fato de que o sedimento mais antigo data desse período em muitos dos abrigos. Ocupações mais antigas poderiam ter ocorrido sem terem sido preservadas.

Como no período anterior, as principais testemunhas de organização interna desses sítios são as estruturas de combustão, as quais são geralmente numerosas nos abrigos. A densidade importante de carvões e de cinzas constitui, às vezes, camadas mais ou menos espessas que pontuam a estratigrafia. Na sequência de Pedra Furada, os tipos de estruturas descritos nos níveis pleistocênicos perduram, mas aparecem também fogueiras em cova (Parenti, 2001). O mesmo é observado em Sítio do Meio, onde escavou-se uma impressionante estrutura de combustão de $98 \times 68 \mathrm{~cm}$, com uma dúzia de blocos erguidos em posição vertical sobre uma grande laje (Figura 10), a qual foi datada de $9.760 \mathrm{AP}^{35}$.

$358.800 \pm 50$ AP não calibrado (Melo, 2007).

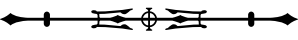


Alguns casos de ordenamento de pisos de ocupação são mencionados nas publicações. No Fundo do Baixão da Pedra Furada, encontrou-se um pavimento produzido com blocos de arenito, agrupados em um conjunto contínuo, associado a uma data de $8.130 \mathrm{AP}^{36}$ (Guidon et al., 2009).

\section{Comportamentos técnicos}

Uma síntese sobre as indústrias líticas da Serra da Capivara foi apresentada recentemente para toda a sequência cronológica da pré-história em duas publicações (Lourdeau; Pagli, 2014; Pagli et al., 2016). Esse apanhado baseia-se nas análises efetuadas em uma dúzia de sítios da região, sete deles tendo níveis arqueológicos datados da transição Pleistoceno-Holoceno e do Holoceno inicial. Extraímos as informações apresentadas a seguir desses dois trabalhos.

Esse período é marcado por elementos de continuidade e de mudança em relação às indústrias do Pleistoceno. Quanto às matérias-primas, seixos de quartzo e de quartzito continuam sendo amplamente usados, mas o painel se diversifica. Sílex, calcedônia e arenito silicificado, em formas de blocos ou seixos, passam a ocupar papel fundamental para a produção dos instrumentos de pedra.

As novidades mais marcantes quanto às produções de pedra lascada dizem respeito à estruturação dos instrumentos e aos modos de produção, com investimento particular nos métodos de 'façonagem'. O objeto classicamente destacado para evocar essa mudança técnica é a peça façonada unifacialmente, também chamada de lesma ou plano-convexo (Figuras 11A a 11C). Com ela, percebe-se o desenvolvimento da 'façonagem' unifacial, que afeta, de maneira mais ou menos intensa, a face superior do suporte original em toda sua periferia, criando, assim, um volume novo, com características próprias, alongado e globalmente simétrico no eixo longitudinal. As análises estruturais dessas peças sugerem que se trata de um suporte de vários instrumentos e que tem uma longa vida útil.

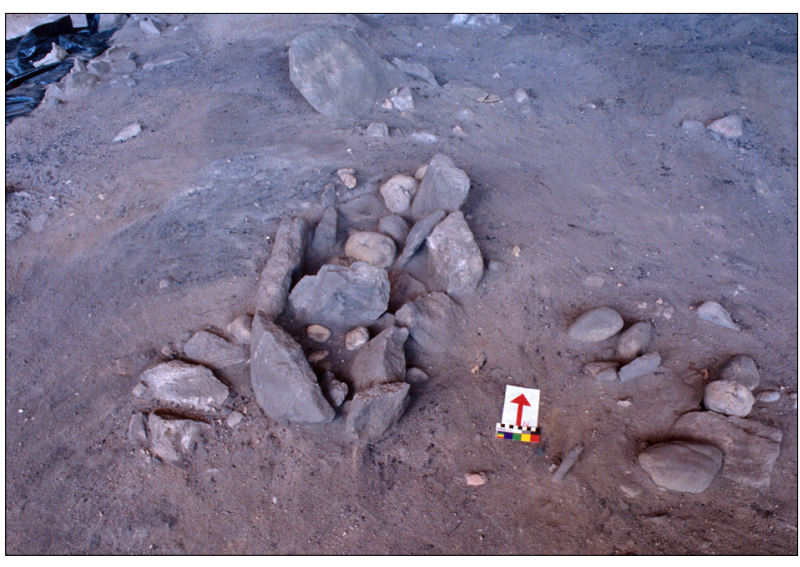

Figura 10. Sítio do Meio. Estrutura de combustão com pedras erguidas datada do Holoceno inicial. Fonte: Arquivos da Fundação Museu do Homem Americano (FUMDHAM) (2010).

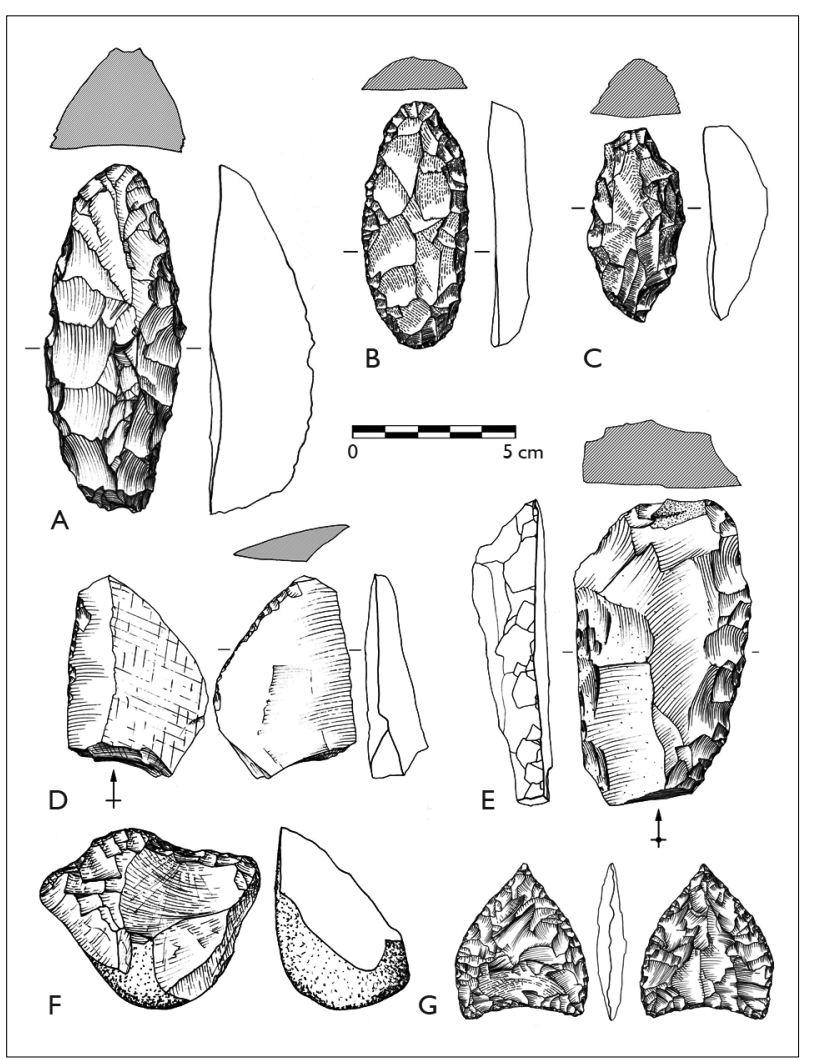

Figura 11. Exemplos de instrumentos líticos encontrados nos níveis do Holoceno inicial na Serra da Capivara em Cabaceiras (A e F); em Pica-Pau (B, C e G); e em Pedra Furada, fase ST1 (D e E). Fonte: Lourdeau e Pagli (2014, p. 583, 584, 606 e 610).

$367.380 \pm 40$ AP não calibrado (Guidon et al., 2009).

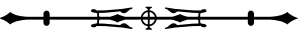


A mudança corresponde à reelaboração inteira do sistema técnico, e não somente à introdução desse novo suporte de instrumento. O conjunto técnico baseia-se na complementaridade funcional entre essas peças façonadas unifacialmente e diferentes outros instrumentos, os quais, por sua vez, são produzidos sobre lascas retocadas e apresentam certa padronização volumétrica. A lateralização desses objetos é bastante marcada, com um gume no lado mais comprido, oposto a um dorso abrupto (Figuras 11D e 11E). A 'façonagem' bifacial aparece também para a produção de pontas de projétil (Figura 11G). Essas ocorrências são raras, indicando que a aquisição dos recursos cárneos não dependia da produção de armas de pedra.

Essa reelaboração do sistema técnico não corresponde a uma renovação total. Existem elementos de continuidade com as produções anteriores. $O$ seixo perdura enquanto suporte, não somente como matéria-prima, mas também como volume (Figura 11F). Instrumentos continuam sendo produzidos sobre esses suportes, selecionados entre as formas disponíveis no entorno dos abrigos. Os mesmos tipos de instrumentos continuam sendo produzidos, como os 'rostres' ou as peças convergentes. Existem diferenças na representação respectiva de cada um. Os instrumentos com gume longitudinal lateral passam a ser mais comuns do que os com gume transversal, em concordância com as tendências do instrumental sobre lascas.

Os conceitos e métodos de debitagem evoluem pouco. As lascas provêm principalmente de curtas séries de retiradas, geralmente unidirecionais, sem preparação preliminar dos núcleos. A percussão unipolar direta com pedra é a técnica mais utilizada, completada pela percussão bipolar sobre bigorna.

Existem indícios de mudanças técnicas ao longo desse período, entre 12.700 e 8.000 anos AP. Os sítios
João Leite e Cerca do Elias apresentam peças façonadas unifacialmente assimétricas, com gume lateral e debitagem laminar associados a contextos da transição PleistocenoHoloceno. Esses elementos de diversidade poderiam revelar um primeiro período de reorganização do sistema técnico, antes de sua consolidação e fixação a partir do início do Holoceno antigo.

Esses comportamentos técnicos perduram até 8.000 a 7.000 AP, momento a partir do qual se observa uma nova mudança importante dos modos de produção e da estruturação dos instrumentos.

A bibliografia sobre a Serra da Capivara menciona descobertas surpreendentes referentes à sua antiguidade, considerando a sequência arqueológica macrorregional. Fragmentos de cerâmica associados a carvões datados de $10.030^{37}$ e $8.130 \mathrm{AP}^{38}$ foram encontrados nas escavações do Sítio do Meio e do Fundo do Baixão da Pedra Furada, respectivamente (Guidon; Pessis, 1993; Guidon et al., 2002). No Sítio do Meio, uma lâmina de machado polida foi associada a um carvão datado em 10.330 AP ${ }^{39}$ (Guidon; Pessis, 1993). Mais descobertas e mais dados contextuais seriam necessários para confirmar idades tão remotas para essas invenções técnicas, mas, se considerarmos as descobertas feitas na Amazônia ou em Minas Gerais, essa cronologia não seria inconsistente (Roosevelt et al., 1991; Sousa; Araujo, 2018).

\section{Comportamentos de subsistência}

Poucos dos níveis arqueológicos da transição PleistocenoHoloceno e do Holoceno inicial continham restos vegetais e ósseos. Quanto ao mundo vegetal, macrorrestos de cabaça, coco de maniçoba, sementes de abóbora e de algodão foram identificados no Sítio do Meio (Melo, 2007). Pólens encontrados em coprólitos humanos de Pedra Furada demostram um amplo conhecimento da

$378.960 \pm 70$ AP não calibrado.

$387.380 \pm 40$ AP não calibrado.

$399.200 \pm 60$ AP não calibrado.

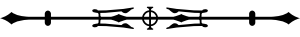


diversidade e das propriedades das plantas desde 9.000 anos atrás, com fins tanto alimentares (Phaseolus sp., Anacardium sp., Cucurbitaceae, Convolvulaceae, Palmae) quanto terapêuticos (Borreria sp., Sida sp., Terminalia sp.) (Chaves, 2002; Chaves; Reinhard, 2006). Os carvões oriundos do mesmo sítio contêm elementos de vários gêneros conhecidos pelas suas propriedades medicinais e alimentares (Anadenanthera, Tabebuia, Spondias, Anacardium). Sugerem um uso não somente como combustível (Mota, 2017).

No que diz respeito à fauna consumida, em Coqueiros, 15 espécies de vertebrados estão associadas a estruturas de combustão e ao sepultamento. Tratase, principalmente, de tatus (Dasypus sp., Tolypeutes tricinctus, Euphractus sexcinctus), rato rabudo (Thrichomys apereoides), cágado (Mesoclemmys sp.), cutia (Dasyprocta sp.), mocó (Kerodon rupestris) e seriema (Cariama cristata) (Barbosa, 2017). No Sítio do Meio, foram encontrados, associado a fogueiras do Holoceno inicial, principalmente restos de tatu (Dasypodidae), mocó (Kerodon rupestris), rato (Trichomys sp.), gambá (Didelphidae) e cervídeos (Cervidae) (Melo, 2007). Todos os táxons identificados referem-se a espécies atuais.

Esses dados apontam para um amplo espectro alimentar, ou seja, para a exploração de toda a variabilidade dos recursos naturais disponíveis.

\section{Comportamentos simbólicos}

Os grafismos rupestres encontrados em grande quantidade na região constituem os testemunhos mais ricos dos comportamentos simbólicos das populações pré-históricas da Serra da Capivara. Existe uma rede de evidências apontando para datas que recuam pelo menos ao
Holoceno inicial para parte deles. As dificuldades de datação absoluta dificultam uma integração na mesma temporalidade daquela dos vestígios encontrados dentro dos sedimentos. Remete-se à pletórica bibliografia existente sobre a arte rupestre da região ${ }^{40}$.

Trataremos aqui mais especificamente dos sepultamentos, que abrem discussão sobre as relações entre vivos e mortos. Existem inumações da transição Pleistoceno-Holoceno e do Holoceno inicial em cinco sítios: Coqueiros, Antonião, Sítio do Meio, Boa Vista II e Paraguaio ${ }^{41}$ (Quadro 2 e Apêndice 1). Para três enterramentos, a preservação do esqueleto e a documentação publicada permitem entender o modo de deposição, bastante similar nos três casos. Trata-se de enterramentos primários de adultos em decúbito lateral fletido. Os sepultamentos são sempre associados a estruturas de combustão. Os sedimentos circundando os corpos são ricos em cinzas. Pedras são dispostas ao redor. Em Coqueiros e Antonião, o corpo foi deitado sobre lajes em uma superfície levemente côncava. Em Paraguaio, sobre seixos dentro de uma cova. Em Coqueiros e Paraguaio, a estrutura funerária estava delimitada por pedras, blocos de arenito e seixos de quartzo, respectivamente. Somente em Coqueiros existe um enxoval bem caracterizado: 21 peças líticas, entre as quais duas pontas de projétil.

O sepultamento de Sítio do Meio diverge desse padrão. Trata-se de restos de uma criança, dos quais somente os dentes se conservaram. $O$ enxoval encontra-se mais rico do que nas sepulturas de adultos. Compõe-se de um fino colar de mais de mil pequenas sementes, em diferentes fieiras, e de uma placa de pigmento de ocre com marcas de uso.

\footnotetext{
40 Por exemplo, ver Guidon (1991) e Pessis (2013).

${ }^{41}$ Na publicação referente a Antonião (Peyre, 1994), a morte acidental do indivíduo, sem intenção sepulcral da deposição, é mencionada como uma possibilidade. No entanto, a boa preservação do esqueleto, a ausência de indícios de morte violenta e de doenças, sua posição, bem como o arranjo de cinza a seu redor advogam para uma interpretação funerária com muita probabilidade. Não dispomos de informação publicada sobre o sepultamento de Boa Vista II. No que diz respeito ao Sítio Paraguaio, levamos em consideração aqui somente a sepultura 2, por questões de datação frisadas acima. A origem sepulcral dos restos de Cerca de Elias, ainda que provável, não é comprovada.
}

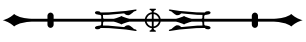


Um elemento recorrente desses comportamentos funerários do Holoceno inicial é o uso de fogueiras no ritual de enterramento. Nos sítios em contexto arenítico, onde o solo é ácido, a forte proporção de cinzas no sedimento dos sepultamentos permitiu uma boa conservação dos ossos.

\section{Contextualização macrorregional}

O aumento de sítios na Serra da Capivara depois da transição Pleistoceno-Holoceno coincide com uma tendência idêntica em todo o Brasil central (Bueno et al., 2013). O perfil cultural geral ora descrito corresponde, nas grandes linhas, ao contexto macrorregional. No plano técnico, a indústria lítica enquadra-se dentro do Tecnocomplexo Itaparica. Esse sistema baseado na complementaridade entre peças façonadas unifacialmente e instrumentos sobre lascas encontra-se na grande maioria dos sítios do Holoceno inicial do Brasil central e sugere a unidade do fenômeno de consolidação da ocupação desse amplo território (Lourdeau, 2010, 2015; Bueno; Isnardis, 2018). No entanto, dentro desse quadro, a Serra da Capivara manifesta especificidades locais, como o uso notável dos seixos como suportes de instrumentos. Os dados relativos à subsistência apontam, como na Serra da Capivara, para atividades de caça e de coleta generalizadas (Kipnis, 1998; Schmitz, P. et al., 2004). Quanto aos comportamentos funerários, os padrões variam nos sítios do Centro e do Nordeste do período, mas é recorrente a modalidade primária das inumações dos adultos, sendo comum a associação com fogueiras (Prous et al., 2011; Martin, 1994).

\section{PERSPECTIVAS}

A convergência do grande potencial arqueológico da Serra da Capivara e de um esforço de pesquisa considerável na área produziu a quantidade de dados brevemente sintetizados neste artigo. Com uma concentração ímpar de sítios pleistocênicos e um abundante registro arqueológico para a transição Pleistoceno-Holoceno e o Holoceno inicial, a região é um local privilegiado para abordar, no tempo longo, os processos de povoamento e os comportamentos humanos associados. Os elementos de continuidade e de mudança entre Pleistoceno final e Holoceno inicial oferecem, por exemplo, uma oportunidade de estudar a emergência do Tecnocomplexo Itaparica e sua relação com o substrato cultural anterior. Com o presente artigo, esperamos ter contribuído para realçar a quantidade de informações que se tem na área para estudar os primeiros povoamentos. Esses dados vão bem além dos níveis pleistocênicos de Pedra Furada e são ausentes da maioria das sínteses macrorregionais ou continentais sobre a pré-história antiga. Direções futuras das pesquisas poderão tratar da integração desses dados com os inúmeros grafismos rupestres da região, cuja parte poderia datar do Holoceno inicial ou mais. Esse estudo e outros, como o das fontes e das modalidades de abastecimento das matérias-primas, combinados com os elementos já conhecidos, contribuirão para o entendimento dos processos de ocupação do espaço e da construção dos territórios ao longo dos milênios.

\section{AGRADECIMENTOS}

Sou grato a Claide de Paula Moraes e a Lucas Bueno, pelo convite para publicar neste número da revista e pelo incentivo a tratar do presente assunto. Como trabalho de síntese, este artigo apoiou-se sobre as produções de numerosos pesquisadores, que convém agradecer aqui, especificamente a Niède Guidon, que dedicou sua vida à Serra da Capivara. Sou também grato a Anne-Marie Pessis, Gisele Felice, como a todos os funcionários da FUMDHAM. A Michel Rasse e Eric Boëda, responsáveis sucessivos da missão arqueológica franco-brasileira no Piauí. As discussões a propósito das datações com Christelle Lahaye, Michel Fontugne, Christine Hatté e Hélène Valladas foram fundamentais. Agradeço a André Strauss e a Christophe Griggo, por terem disponibilizado publicações que estavam no prelo; a Patrícia Pinheiro de Melo e a Pétrius da Silva Bélo, por terem permitido o uso 
de figuras suas; e a Lívia Lucas e a Claide de Paula Moraes, pela releitura do texto. Esta publicação foi realizada no âmbito do projeto "O povoamento inicial da América a partir do contexto arqueológico brasileiro", financiado pelo programa de cooperação da Coordenação de Aperfeiçoamento de Pessoal de Nível Superior/Comité Français d'Évaluation de la Coopération Universitaire et Scientifique avec le Brésil (CAPES-COFECUB) (n. 840/15).

\section{REFERÊNCIAS}

AIMOLA, Giulia; ANDRADE, Camila; MOTA, Leidiana; PARENTI, Fabio. Final Pleistocene and early Holocene at Sitio do Meio, Piauí, Brazil: stratigraphy and comparison with Pedra Furada. Journal of Lithic Studies, United, Kingdom, v. 1, n. 2, p. 5-24, Sept. 2014. DOI: https://doi.org/10.2218/jls.v1i2.1125

ALMEIDA, Tatiana F. de; NEVES, Walter A. Remanescentes ósseos humanos da Toca do Serrote das Moendas: cura, inventário e descrição sumária. Fumdhamentos, São Raimundo Nonato, v. 8, p. 86-93, 2009.

ALVIM, M. C. M.; FERREIRA, F. J. L. C. Os esqueletos do abrigo Toca do Paraguaio, município de São Raimundo Nonato, Piauí: estudo antropofísico. Cadernos de Pesquisa. Serie Antropologia III, Piauí, v. 4, p. 239-261, 1985.

ARNAUD, Marie-Bernadette; EMPERAIRE, L.; GUIDON, Niède; PELLERIN, J. L'aire archéologique du Sud-Est du Piauí (Brésil). Paris: Recherches sur les Civilisations, 1984.

BARBOSA, Maria de Fatima Ribeiro. Associações funcionais entre o homem pré-histórico e a fauna holocênica na Serra da Capivara. 2017. Tese (Doutorado em Arqueologia) - Universidade Federal de Pernambuco, Pernambuco, 2017.

BEHLING, Hermann; ARZ, Helge W.; PÄTZOLD, Jürgen; WEFER, Gerold. Late Quaternary vegetational and climate dynamics in northeastern Brazil, inferences from marine core GeoB 3104-1. Quaternary Science Reviews, Amsterdam, v. 19, n. 10, p. 981-994, June 2000. DOI: https://doi.org/10.1016/S0277-3791(99)00046-3.

BÉLANGER, N.; CARCAILLET, C.; PADBURY, G. A.; HARVEYSCHAFER, A. N.; REES, K. J. C. Periglacial fires and trees in a continental setting of Central Canada, Upper Pleistocene. Geobiology, Hoboken, v. 12, n. 2, p. 109-118, Mar. 2014. DOI: https://doi.org/10.1111/gbi.12076.

BÉLO, Pétrius da Silva. Alterações antrópicas em restos fósseis da megafauna: tafonomia do sítio arqueológico e paleontológico "Toca da Janela da Barra do Antonião", área arqueológica do Parque Nacional Serra da Capivara, Piauí, Brasil. 2012. Dissertação (Mestrado em Arqueologia) - Universidade Federal Pernambuco, Pernambuco, 2012.
BERNARDO, Danilo V.; NEVES, WalterA. Diversidade morfocraniana dos remanescentes ósseos humanos da Serra da Capivara: implicações para a origem do homem americano. Fumdhamentos, São Raimundo Nonato, v. 8, p. 95-106, dez. 2009.

BOËDA, Eric; ROCCA, Roxane; DA COSTA, Amélie; FONTUGNE, Michel; HATTÉ, Christine; CLEMENTE-CONTE, Ignacio; SANTOS, Janaina C.; LUCAS, Lívia; FELICE, Gisèle; LOURDEAU, Antoine; VILLAGRAN, Ximena; GLUCHY, Maria; RAMOS, Marcos Paulo; VIANA, Sibeli; LAHAYE, Christelle; GUIDON, Niède; GRIGGO, Christophe; PINO, Mario; PESSIS, Anne-Marie; BORGES, Carolina; GATO, Bruno. New data on a Pleistocene archaeological sequence in South America: Toca do Sítio do Meio, Piauí, Brazil. PaleoAmerica, London, v. 2, n. 4, p. 286-302, Oct. 2016. DOI: https://doi.org/10 .1080/20555563.2016.1237828.

BOËDA, Eric. Deve-se recear as indústrias sobre seixo? Análise comparativa entre as indústrias pleistocênicas da Ásia Oriental e da América do Sul. In: LOURDEAU, A.; VIANA, S. A.; RODET, M. J. (org.). Indústrias líticas na América do Sul: abordagens teóricas e metodológicas. Recife: UFPE, 2014. p. 11-36.

BOËDA, Eric; CLEMENTE-CONTE, Ignacio; FONTUGNE, Michel; LAHAYE, Christelle; PINO, Mario; DALTRINI, Gisele Felice; GUIDON, Niéde; HOELTZ, Sirlei; LOURDEAU, Antoine; PAGLI, Marina; PESSIS, Anne-Marie; VIANA, Sibeli; DA COSTA, Amélie; DOUVILLE, Eric. A new late Pleistocene archaeological sequence in South America: the Vale da Pedra Furada (Piauí, Brasil). Antiquity, Cambridge, v. 88, n. 341, p. 927-941, Sept. 2014a. DOI: https://doi. org/10.1017/S0003598X00050845.

BOËDA, Eric; DALTRINI, Gisele Felice; FONTUGNE, Michel; HOELTZ, Sirley; LOURDEAU, Antoine; CHRISTELLE, Lahaye; PAGLI, Marina; VIANA, Sibeli. Les industries pléistocènes du Piauí nouvelles données. In: FARIAS, Maria; LOURDEAU, Antoine (org.). Peuplement de l'Amérique du sud: i'apport de la technologie lithique. Prigonrieux: Archéo-éditions, 2014b. p. 13-63.

BOËDA, Eric; LOURDEAU, Antoine; LAHAYE, Christelle; FELICE, Gisele Daltrini; VIANA, Sibeli; CLEMENTE-CONTE, Ignacio; PINO, Mario; FONTUGNE, Michel; HOELTZ, Sirlei; GUIDON, Niède; PESSIS, Anne-Marie; DA COSTA, Amélia; PAGLI, Marina. The LatePleistocene industries of Piauí, Brazil: new data. In: GRAF, Kelly E.; KETRON, Caroline V.; WATERS, Michael R. (ed.). Paleoamerican odyssey. College Station: Texas A\&M University Press, 2014c. p. 445-465.

BONNICHSEN, Robson; LEPPER, Bradley T.; STANFORD, Dennis; WATERS, Michael R. (ed.). Paleoamerican origins: Beyond Clovis. College Station: Texas A\&M University, 2005.

BORRERO, Luis Alberto. Ambiguity and debates on the Early Peopling of South America. PaleoAmerica, London, v. 2, n. 1, p. 11-21, Mar. 2016. DOI: https://doi.org/10.1080/20555563.2015.1136498.

BORRERO, Luis Alberto. Con lo mínimo: los debates sobre el poblamiento de América del Sur. InterSecciones en Antropologia, Buenos Aires, v. 16, n. 1, p. 5-38, jun. 2015.

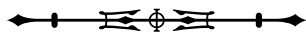


BOURGEON, Lauriane; BURKE, Ariane; HIGHAM, Thomas. Earliest human presence in North America dated to the last glacial maximum: new radiocarbon dates from bluefish caves, Canada. PLOS ONE, San Francisco, v. 12, n. 1, p. 1-15, Jan. 2017. DOI: https://doi.org/10.1371/ journal.pone.0169486.

BRAJE, Todd J.; DILLEHAY, Tom D.; ERLANDSON, Jon M.; KLEIN, Richard G.; RICK, Torben C. Finding the first Americans. Science, Washington, v. 358, n. 6363, p. 592-594, Nov. 2017. DOI: https:// doi.org/10.1126/science.aao5473.

BRYAN, Alan Lyle (ed.). New evidence for the pleistocene peopling of the Americas. Orono: Center for the Study of Early Man: University of Maine, 1986.

BUENO, Lucas; ISNARDIS, Andrei. Peopling Central Brazilian Plateau at the onset of the Holocene: building territorial histories. Quaternary International, Amsterdam, v. 473, p. 144-160, Apr. 2018. Parte B. DOI: https://doi.org/10.1016/j.quaint.2018.01.006.

BUENO, Lucas; DIAS, Adriana Schmidt; STEELE, James. The late Pleistocene/Early Holocene archaeological record in Brazil: a georefenced database. Quaternary International, Amsterdam, v. 301, p. 74-93, July 2013. DOI: https://doi.org/10.1016/J.quaint.2013.03.042.

CHAVES, Sérgio Augusto de Miranda; REINHARD, Karl J. Critical analysis of coprolite evidence of medicinal plant use, Piauí, Brazil. Palaeogeography, Palaeoclimatology, Palaeoecology, Amsterdam, v. 237, n. 1, p. 110-118, July 2006. DOI: https://doi.org/10.1016/j. palaeo.2005.11.031.

CHAVES, Sérgio Augusto de Miranda. História das Caatingas: a reconstituição paleoambiental da região arqueológica do Parque Nacional Serra da Capivara através da Palinologia. Fumdhamentos, São Raimundo Nonato, v. 1, n. 2, p. 85-103, 2002.

CUNHA, E. Análise antropológica de 15 esqueletos. In: PESSIS, AnneMarie; MARTIN, Gabriela; GUIDON, Niède (org.). Os biomas e as sociedades humanas na pré-história: região do Parque Nacional Serra da Capivara, Brasil. São Paulo: A\&A, 2014. v. II-A, p. 318-379.

DA COSTA, Amélie. Rupture technique et dynamiques d'occupation au cours de l'Holocène moyen au Brésil. 2017. Tese (Doutorado em Pré-História) - Universidade de Paris Nanterre, Nanterre, 2017.

DIAS, Adriana Schmidt; BUENO, Lucas M. R. More of the same. Antiquity, Cambridge, v. 88, n. 341, p. 943-945, Sept. 2014. DOI: https://doi.org/10.1017/S0003598X00050869.

DILLEHAY, Tom D. The late Pleistocene cultures of South America. Evolutionary Anthropology, Hoboken, v. 7, n. 6, p. 206-215, May 1999. DOI: https://doi.org/10.1002/(SICI)15206505(1999)7:6<206::AID-EVAN5>3.0.CO;2-G.

EMPERAIRE, Laure. La caatinga du sud-est du Piaui (Brésil): étude ethnobotanique. Paris: Editions Recherche sur les Civilisations, 1983. (Mémoire, n. 21).
FAGUNDES, Nelson I. R.; KANITZ, Ricardo; BONATTO, Sandro L. A reevaluation of the Native American MtDNA Genome Diversity and its bearing on the models of early colonization of beringia. PLOS ONE, San Francisco, v. 3, n. 9, p. 1-5, Sept. 2008. DOI: https://doi. org/10.1371/journal.pone.0003157.

FAURE, Martine; GUÉRIN, Claude; PARENTI, Fabio. Découverte d'une mégafaune holocène à la Toca do Serrote do Artur (aire archéologique de São Raimundo Nonato, Piauí, Brésil). Comptes Rendus de l'Académie des Sciences: series IIA - Eart and Planetary Science, Paris, v. 329, n. 6, p. 443-448, Sept. 1999. DOI: https:// doi.org/10.1016/S1251-8050(00)80069-5.

FEATHERS, James; KIPNIS, Renato; PILÓ, Luis; ARROYOKALIN, Manuel; COBLENTZ, David. How old is Luzia? Luminescence dating and stratigraphic integrity at Lapa Vermelha, Lagoa Santa, Brazil. Geoarchaeology: an internacional Journal, Hoboken, v. 25, n. 4, p. 395-436, June 2010. DOI: https://doi. org/10.1002/gea.20316.

FELICE, Gisele Daltrini. Contribuição para estudos geoarqueológicos e paleoambientais: proposta metodológica (estudo de caso: Maciço Calcário do Garrincho, Piauí, Brasil). 2006. Tese (Doutorado em História) - Universidade Federal de Pernambuco, Recife, 2006.

FELICE, Gisele Daltrini. A controvérsia sobre o sítio arqueológico Toca do Boqueirão da Pedra Furada, Piauí - Brasil. Fumdhamentos, São Raimundo Nonato, v. 1, n. 2, p. 143-178, 2002.

FIEDEL, Stuart J. Did monkeys make the Pre-Clovis pebble tools of northeastern Brazil? PaleoAmerica, London, v. 3, n. 1, p. 6-12, Feb. 2017. DOI: https://doi.org/10.1080/20555563.2016.1273000.

FONTUGNE, Michel. New radiocarbon ages of Luzia woman, Lapa Vermelha IV Site, Lagoa Santa, Minas Gerais, Brazil. Radiocarbon, Cambridge, v. 55, n. 3, p. 1187-1190, Feb. 2013. DOI: https://doi. org/10.1017/S0033822200048098.

GALLAND, Manon; FRIESS, Martin. A three-dimensional geometric morphometrics view of the cranial shape variation and population history in the new world. American Journal of Human Biology, Amherst, v. 28, n. 5, p. 646-661, Feb. 2016. DOI: https://doi. org/10.1002/ajhb.22845.

GALLAND, Manon. Le premier peuplement des Amériques: application de la morphométrie géométrique $3 \mathrm{D}$ à la variation crâniense actuelle et fossile. 2013. Tese (Doutorado em Paleontropologia) - Museu Nacional de História Natural, Paris, 2013.

GOEBEL, Ted; WATERS, Michael R.; O'ROURKE, Dennis $H$. The late Pleistocene dispersal of modern humans in the Americas. Science, Washington, v. 319, n. 5869, p. 1497-1502, Mar. 2008. DOI: $10.1126 /$ science.1153569.

GRAF, Kelly E.; KETRON, Caroline V.; WATERS, Michael R. (ed.) Palaeoamerican Odyssey. College Station: Texas A\&M University, 2013.

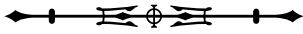


GRIGGO, Christophe; DE SOUZA, Iderlan; BOËDA, Éric; FONTUGNE, Michel; HATTÉ, Christine; LOURDEAU, Antoine; GUIDON, Niède. La faune du Pléistocène supérieur - Holocène ancien de la Toca da Pena (Piauí, Brésil) - étude paléontologique. Quaternaire, Paris, v. 29, n. 3, p. 205-216, 2018.

GUÉRIN, Claude; FAURE, M. Paleontologia da região do Parque Nacional Serra da Capivara. In: PESSIS, Anne-Marie; MARTIN, Gabriela; GUIDON, Niède (org.). Os biomas e as sociedades humanas na pré-história: região do Parque Nacional Serra da Capivara, Brasil. São Paulo: A\&A, 2014. v. II-A, p. 140-183.

GUÉRIN, Claude; FAURE, Martine; SIMÕES, Paulo R.; HUGUENEY, Marguerite; MOURER-CHAUVIRE, Cécile. Toca da Janela da Barra do Antonião, São Raimundo Nonato, PI. In: SCHOBBENHAUS, Carlos; CAMPOS, Diogenes de Almeida; QUEIROZ, Emanuel Teixeira de; WINGE, Manfredo; BERBERT-BORN, Mylène (org.). Sítios geológicos e paleontológicos do Brasil. Brasília: DNPM, 2002. v. 1, p. 131-137.

GUÉRIN, Claude; HUGUENEY, Marguerite; MOURER-CHAUVIRÉ, Cécile; FAURE, M. Paléoenvironnement pléistocène dans l'aire archéologique de São Raimundo Nonato (Piauí, Brésil): apport des mammifères et des oiseaux. In: GAYET, M. (org.). Paléontologie et stratigraphie d'Amérique latine. Lyon: Centre des sciences de la terre, 1993. p. 187-202. (Documents des Laboratoires de Geologie de Lyon, n. 125).

GUIDON, Niède; AQUINO, Crisvanete de Castro; SANTANA, Tânia Maria de Castro; NEVES, Annelise da Silva; ALMEIDA, Maria de Fátima. Sítio Toca da Roça do Justino Aquino VI, Parque Nacional Serra da Capivara. Fumdhamentos, São Raimundo Nonato, n. 12, p. 5-25, 2015.

GUIDON, Niède; PESSIS, Anne-Marie; MARTIN, Gabriela. Pesquisas arqueológicas na região do Parque Nacional Serra da Capivara e seu entorno (Piauí - 1998-2008). Fumdhamentos, São Raimundo Nonato, n. 8, p. 1-61, 2009.

GUIDON, Niède; BUCO, Cristiane de A.; IGNÁCIO, E. Escavações em três abrigos da Serra Branca. Fumdhamentos, São Raimundo Nonato, v. 6, p. 52-73, 2007.

GUIDON, Niède. Contribuição ao estudo da paleogeografia da área do Parque Nacional Serra da Capivara. Clio. Série Arqueológica, Recife, n. 15, p. 45-60, 2002.

GUIDON, Niède; VIDAL, Irma A.; BUCO, Cristiane de A.; SALVIA, Eliany S. La; FELICE, Gisele D.; PINHEIRO, Patricia. Notas sobre a pré-história do Parque Nacional Serra da Capivara. Fumdhamentos, São Raimundo Nonato, v. 1, n. 2, p. 105-141, 2002.

GUIDON, Niède; PEYRE, Evelyne; GUÉRIN, Claude; COPPENS, Yves. Resultados da datação de dentes humanos da Toca do Garrincho, Piauí - Brasil. Clio. Série Arqueológica, Recife, n. 14, p. 75-86, 2000.
GUIDON, Niède; PARENTI, Fabio; OLIVEIRA, Claudia; VERGNE, Cleonice. Nota sobre a sepultura da Toca dos Coqueiros, Parque Nacional Serra da Capivara, Brasil. Clio. Série Arqueológica, Recife, v. 1, n. 13, p. 187-197, 1998.

GUIDON, Niède; PESSIS, Anne-Marie. Falsehood or untruth? Antiquity, Cambridge, v. 70, n. 268, p. 408-415, June 1996. DOI: https://doi.org/10.1017/S0003598×00083368.

GUIDON, Niède; PARENTI, Fabio; LUZ, Maria de Fátima da; GUÈRIN, Claude; FAURE, Martine. Le plus ancien peuplement de l'Amérique: le paléolithique du Nordeste brésilien. Bulletin de la Société Préhistorique Française, France, t. 91, n. 4/5, p. 246-250, 1994.

GUIDON, Niède; PESSIS, Anne-Marie. Recent discoveries on the holocenic levels of sítio do Meio rock-shelter, Piauí Brasil. Clio. Série Arqueológica, Recife, v. 1, n. 9, p. 77-80, 1993.

GUIDON, Niède. Peintures préhistoriques du Brésil: l'art rupestre du Piauí. Paris: Editions Recherche sur les Civilisations, 1991.

GUIDON, Niède. Notas sobre dois sítios da área arqueológica de São Raimundo Nonato - Piauí. Clio. Série arqueológica, Recife, v. 1, n. 5, p. 41-47, 1989.

GUIDON, Niède; DELIBRIAS, G. Carbon-14 dates point to man in the Americas 32.000 years ago. Nature, London, v. 321, p. 769-771, June 1986. DOI: https://doi.org/10.1038/321769a0.

GUIDON, Niède. Unidades culturais da tradição Nordeste na área arqueológica de São Raimundo Nonato. Revista do Museu Paulista. Nova Série, São Paulo, v. 30, p. 115-147, 1985.

GUIDON, Niède. Las unidades culturales de São Raimundo Nonato, sudeste del estado de Piauí. In: BRYAN, A. L. (org.). El Poblamiento de América. Mexico: UISPP, 1981. p. 101-111.

GUIDON, Niède; ANDREATTA, Margarida D. O sítio arqueológico Toca do Sítio do Meio, Piauí. Clio: Revista de Pesquisa Histórica, Recife, n. 3, p. 7-29, 1980.

HAYNES JÚNIOR, C. Vance. The earliest Americans. Science, Washington, v. 166, n. 3906, p. 709-715, Nov. 1969. DOI: https:// doi.org/10.1126/science.166.3906.709.

HAYNES, Gary. The early settlement of North America: the Clovis Era. New York: Cambridge University Press, 2002.

HUBBE, Mark; NEVES, Walter A. A repercussão dos esqueletos humanos de Lagoa Santa no cenário internacional. In: DAGLORIA, Pedro; NEVES, Walter A.; HUBBE, Mark (org.). Lagoa Santa: histórias das pesquisas arqueológicas e paleontológicas. São Paulo: Annablume, 2016. p. 229-248. 
HUBBE, Mark; NEVES, Walter A.; HARVATI, Katerina. Testing evolutionary and dispersion scenarios for the settlement of the new world. PLOS ONE, San Francisco, v. 5, n. 6, p. 1-9, June 2010. DOI: https://doi.org/10.1371/journal.pone.0011105.

HUBBE, Mark; NEVES, Walter A.; AMARAL, Heleno Licurgo do; GUIDON, Niède. Brief communication: "Zuzu" strikes againmorphological affinities of the early holocene human skeleton from Toca dos Coqueiros, Piauí, Brazil. American Journal of Physical Anthropology, Hoboken, v. 134, n. 2, p. 285-291, Oct. 2007. DOI: https://doi.org/10.1002/ajpa.20668.

KINOSHITA, Angela; SKINNER, Anne R.; GUIDON, Niède; IGNACIO, Elaine; FELICE, Gisele Daltrini; BUCOD, Cristiane de A.; TATUMI, Sonia; YEE, Márcio; FIGUEIREDO, Ana Maria Graciano; BAFFA, Oswaldo. Dating human occupation at Toca do Serrote das Moendas, São Raimundo Nonato, Piauí-Brazil by electron spin resonance and optically stimulated luminescence. Journal of Human Evolution, Amsterdam, v. 77, p. 187-195, Dec. 2014. DOI: https:// doi.org/10.1016/j.jhevol.2014.09.006.

KIPNIS, Renato. Early hunter-gatherers in the Americas: perspectives from central Brazil. Antiquity, Cambridge, v. 72, n. 277, p. 581-592, Sept. 1998. DOI: https://doi.org/10.1017/S0003598X00087019.

LAHAYE, Christelle; GUÉRIN, Guillaume; GLUCHY, Maria; HATTÉ, Christine; FONTUGNE, Michel R.; CLEMENTE-CONTE, Ignacio; SANTOS, Janaina C.; VILLAGRAN, Ximena S.; DA COSTA, Amélie; BORGES, Carolina; GUIDON, Niède; BOËDA, Eric. Another site, same old song: the pleistocene-holocene archaeological sequence of Toca da Janela da Barra do Antonião-Norte, Piauí, Brazil. Quaternary Geochronology, Amsterdam, v. 49, p. 223-229, Feb. 2019. DOI: https://doi.org/10.1016/j.quageo.2018.03.006.

LAHAYE, Christelle; GUÉRIN, Guillaume; BOËDA, Eric; FONTUGNE, Michel R.; HATTÉ, Christine; FROUIN, Marine; CLEMENTE-CONTE, Ignacio; PINO, Mario A.; FELICE, Gisèle Daltrini; GUIDON, Niède; LOURDEAU, Antoine; PAGLI, Marina; PESSIS, Anne Marie; DA COSTA, Amélie. New insights into a late-Pleistocene human occupation in America: the Vale da Pedra Furada complete chronological study. Quaternary Geochronology, Amsterdam, v. 30, p. 445-451, Oct. 2015. DOI: https://doi. org/10.1016/j.quageo.2015.03.009.

LAHAYE, Christelle; HERNANDEZ, Marion; BOËDA, Eric; FELICE, Gisele D.; GUIDON, Niède; HOELTZ, Sirlei; LOURDEAU, Antoine; PAGLI, Marina; PESSIS, Anne-Marie; RASSE, Michel; VIANA, Sibeli. Human occupation in South America by 20,000 BC: the Toca da Tira-Peia site, Piauí, Brazil. Journal of Archaeological Science, Amsterdam, v. 40, n. 6, p. 2840-2847, June 2013. DOI: https://doi.org/10.1016/j.jas.2013.02.019.

LEDRU, Marie-Pierre; CECCANTINI, Gregorio; GOUVEIA, Susy E. M.; LÓPEZ-SÁEZ, José Antonio; PESSENDA, Luiz C. R.; RIBEIRO, Adauto S. Millenial-scale climatic and vegetation changes in a northern Cerrado (Northeast, Brazil) since the Last Glacial Maximum. Quaternary Science Reviews, Amsterdam, v. 25, n. 9/10, p. 11101126, May 2006. DOI: https://doi.org/10.1016/J.quascirev.2005.10.005.
LEE, Michael S. Y.; HO, Simon Y. W. Molecular clocks. Current Biology, Cambridge, v. 26, p. R387-R407, May 2016.

LESSA, Andrea; GUIDON, Niède. Osteobiographic analysis of skeleton I, Sitio Toca dos Coqueiros, Serra da Capivara National Park, Brazil, 11,060 BP: first results. American Journal of Physical Anthropology, Hoboken, v. 118, n. 2, p. 99-110, June 2002. DOI: https://doi.org/10.1002/ajpa.10084.

LOURDEAU, Antoine. Lithic technology and prehistoric settlement in central and northeast Brazil: definition and spatial distribution of the Itaparica technocomplex. PaleoAmerica, London, v. 1, n. 1, p. 52-67, 2015. DOI: https://doi.org/10.1179/205555631 4Z.0000000005.

LOURDEAU, Antoine; PAGLI, Marina. Indústrias líticas préhistóricas na região da Serra da Capivara, Piauí, Brasil. In: PESSIS, Anne-Marie; MARTIN, Gabriela; GUIDON, Niède (org.). Os biomas e as sociedades humanas na pré-história: região do Parque Nacional Serra da Capivara, Brasil. São Paulo: A\&A, 2014. v. II-B, p. 551-635.

LOURDEAU, Antoine. Le tecnocomplexe Itaparica: définition techno-fonctionnelle des industries à pièces façonnèes unifacialement à une plane dans le centre et le nordest du Brèsil pendant la transition Plèistocène-Holocène et I'Holocène ancien. 2010. Tese (Doutorado em Pré-história) - Universidade de Paris Ouest Nanterre La Défense, Nanterre, 2010.

LOWERY, Darrin L.; O'NEAL, Michael A.; WAH, John S.; WAGNER, Daniel P.; STANFORD, Dennis ]. Late Pleistocene upland stratigraphy of the western Delmarva Peninsula, USA. Quaternary Science Reviews, Amsterdam, v. 29, n. 11/12, p. 1472-1480, June 2010. DOI: https://doi.org/10.1016/j.quascirev.2010.03.007.

LUCAS, Lívia de Oliveira e. Mudanças técnicas entre o Holoceno inicial e médio: o caso da Toca do João Leite (PI). Habitus, Goiânia, v. 13, n. 2, p. 41-56, jul./dez. 2016. DOI: http://dx.doi.org/10.18224/ hab.v13.2.2015.41-56.

LUZ, M. F. O método de pré-escavação na pesquisa arqueológica: análise de um caso a Toca de Cima do Pilão, Piauí. 1989. Dissertação (Mestrado em História) - Universidade Federal de Pernambuco, Recife, 1989.

LYNCH, Thomas F. Glacial-age man in South America? A critical review. American Antiquity, Cambridge, v. 55, n. 1, p. 12-36, Jan. 1990. DOI: https://doi.org/10.2307/281490.

MARTIN, G. Os rituais funerários na Pré-História do Nordeste. Clio. Série Arqueológica, Recife, v. 1, n. 10, p. 29-46, 1994.

MELO, Patrícia Pinheiro de. A transição do Pleistoceno ao Holoceno no Parque Nacional Serra da Capivara-Piaúi-Brasil: uma contribuição ao estudo sobre a antiguidade da presença humana no sudeste do Piauí. 2007. Tese (Doutorado em História com concentração em Arqueologia brasileira) - Universidade Federal de Pernambuco, Recife, 2007. 
MELO, Patrícia Pinheiro de. Técnicas e métodos de escavação: o caso da Toca do Baixão do Perna I. Clio. Série Arqueológica, Recife, v. 1, n. 10, p. 145-173, 1994.

MELTZER, David J.; ADOVASIO, James M.; DILLEHAY, Tom D. On a Pleistocene human occupation at Pedra Furada, Brazil. Antiquity, Cambridge, v. 68, n. 261, p. 695-714, Dec. 1994. DOI: https://doi. org/10.1017/S0003598X00047414.

MERCIER, Norbert. Datation des sédiments quaternaires par luminescence stimulée optiquement: un état de la question. Quaternaire, Paris, v. 19, n. 3, p. 195-204, 2008.

MICHAB, Mostafa. Apport de la thermoluminescence à l'étude chronologique de deux sites brésiliens du pléistocène. 1999. Tese (Doutorado em Quaternário) - Muséum National D'Histoire Naturelle, Paris, 1999.

MOTA, Leidiana Alves da. Ontem lenha hoje carvão; análise antropológica do Holoceno inicial e médio da Toca do Boqueirão da Pedra Furada (Piaú́ Brasil): paisagem, paleoambiente e paleoetnobotânica. 2017. Dissertação (Mestrado em Arqueologia) - Universidade Federal do Rio de Janeiro, Rio de Janeiro, 2017.

NELSON, Albert Russel. "Osteobiographics" of Dos Coqueiros Paleoindian reconsidered: comment on Lessa an Guidon (2002). American Journal of Physical Anthropology, Hoboken, v. 126, n. 4, p. 401-403, Apr. 2005. DOI: https://doi.org/10.1002/ ajpa. 20072.

PAGLI, Marina; LUCAS, Lívia de Oliveira e; LOURDEAU, Antoine. Proposta de sequência tecnocultural da Serra da Capivara (Piauí) do Pleistoceno Final ao Holoceno recente. Cadernos do CEOM, Chapecó, v. 29, n. 45, p. 243-267, sem. 2016. DOI: http://dx.doi. org/10.22562/2016.45.10.

PARENTI, Fabio; CANNELL, Alan; DEBARD, Evelyne; FAURE, Martine; OKUMURA, Mercedes. Genesis and taphonomy ot the archaeological layers of Pedra Furada rock-shelter, Brazil. Quaternaire, Paris, v. 29, n. 3, p. 255-269, 2018. DOI: https://doi. org/10.4000/quaternaire.10313.

PARENTI, Fabio; GUÉRIN, Claude; MENGOLI, Davide; FAURE, Martine; NATALI, Luca; CHAVES, Sergio Augusto de Miranda; FERRARI, Sonia; VALENÇA, Lucia Manfra. Sondagens na Lagoa do Quari, São Raimundo Nonato, Piauí: campanha 2002. Fumdhamentos, São Raimundo Nonato, v. 3, p. 129-145, 2003.

PARENTI, Fabio. Le gisement quaternaire de Pedra Furada (Piauí, Brésil): stratigraphie, chronologie, évolution culturelle. Paris: Editions Recherche sur les Civilisations, 2001.

PARENTI, Fabio; FONTUGNE, Michel; GUIDON, Niède; GUÉRIN, Claude; FAURE, Martine; DEBARD, Evelyne. Chronostratigraphie des gisements archéologiques et paléontologiques de São Raimundo Nonato. In: EVIN, J.; OBERLIN, C.; DAUGAS, J.-P.; SALLES J. F. (org.). 14C et Archéologie. Paris: Sociéte Préhistorique Française, 2000. p. 327-332.
PARENTI, Fabio; FONTUGNE, Michel; GUÉRIN, Claude. Pedra Furada in Brazil and its "presumed" evidence. Antiquity, Cambridge, v. 70, p. 416-421, June 1996. DOI: https://doi.org/10.1017/ s0003598X0008337X.

PARENTI, Fabio. Estratigrafia do Caldeirão do Rodrigues, São Raimundo Nonato. Clio. Série Arqueológica, Recife, v. 1, n. 11, p. 119-135, 1995-1996.

PELLERIN, J. Unidades de relevo e formações superficiais. In: PESSIS, Anne-Marie; MARTIN, Gabriela; GUIDON, Niède (org.). Os biomas e as sociedades humanas na pré-história: região do Parque Nacional Serra da Capivara, Brasil. São Paulo: A\&A, 2014. v. II-A, p. 58-67.

PESSIS, Anne-Marie; MARTIN, Gabriela; GUIDON, Niède (org.). Os biomas e as sociedades humanas na pré-história: região do Parque Nacional Serra da Capivara, Brasil. São Paulo: A\&A, 2014. 2 v.

PESSIS, Anne-Marie. Imagens da pré-história: os biomas e as sociedades humanas no Parque Nacional Serra da Capivara. São Paulo: FUMDHAM, 2013.

PESSIS, Anne-Marie; GUIDON, Niède. Serra da Capivara National Park, Brazil: cultural heritage and society. World Archaeology, Abingdon, v. 39, n. 3, p. 406-416, Sept. 2007. DOI: https://doi. org/10.1080/00438240701504676.

PEYRE, Evelyne; GRANAT, Jean; GUIDON, Niède. Dentes e crânios humanosfósseis do Garrincho(Brasil)e o povoamentoantigo daAmérica. Fumdhamentos, São Raimundo Nonato, v. 8, p. 62-69, dez. 2009.

PEYRE, Evelyne; GUÉRIN, Claude; GUIDON, Niède; COPPENS, Yves. Des restes humains pléistocènes dans la Grotte du Garrincho, Piauí, Brésil. CRAS. Sciences de la Terre et des Planètes, Paris, v. 327, n. 5, p. 335-360, Sept. 1998. DOI: https://doi.org/10.1016/ S1251-8050(98)80055-4.

PEYRE, Evelyne. L'homme préhistorique de São Raimundo Nonato (Piauí, Brésil). Bulletin de la Société Préhistorique Française, Lyon, v. 91, n. 4/5, p. 251-256, 1994.

POLITIS, Gustavo G.; PRATES, Luciano; PERÉZ, S. Ivan. El poblamiento de América: arqueología y bio-antropología de los primeros americanos. Buenos Aires: Eudeba, 2008. (Colección Ciencia Joven, 35).

POTTER, Ben A.; BEAUDOIN, Alwynne B.; HAYNES, C. Vance; HOLLIDAY, Vance T.; HOLMES, Charles E.; IVES, John W.; KELLY, Robert; LLAMAS, Bastien; MALHI, Ripan; MILLER, Shane; REICH, David; REUTHER, Joshua D.; SCHIFFELS, Stephan; SUROVELL, Tood. Arrival routes of first Americans uncertain. Science, Washington, v. 359, n. 6381, p. 1224-1225, Mar. 2018. DOI: https:// doi.org/10.1126/science.aar8233.

PROFFITT, Tomos; LUNCZ, Lydia V.; FALÓTICO, Tiago; OTTONI, Eduardo B.; TORRE, Ignacio de la; HASLAM, Michael. Wild monkeys flake stone tools. Nature, London, v. 539, n. 7627, p. 85-88, Nov. 2016. DOI: https://doi.org/10.1038/nature20112.

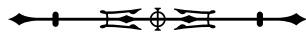


PROUS, André; RODET, Maria Jacqueline; LIMA, Angêlo Pessoa. Les vivants et leurs morts: évocation des rites funéraires dans la préhistoire brésilienne. In: VIALOU, Denis (org.). Peuplements et préhistoire en Amériques. Paris: CTHS, 2011. p. 393-406. (Documents Préhistoriques, 28).

RAGHAVAN, Maanasa; STEINRÜCKEN, Matthias; HARRIS, Kelley; SCHIFFELS, Stephan; RASMUSSEN, Simon; DEGIORGIO, Michael; ALBRECHTSEN, Anders; VALDIOSERA, Cristina; ÁVILA-ARCOS, María C.; MALASPINAS, Anna-Sapfo; ERIKSSON, Anders; MOLTKE, Ida; METSPALU, Mait; HOMBURGER, Julian R.; WALL, Jeff; CORNEJO, Omar E.; MORENOMAYAR, Víctor; KORNELIUSSEN, Thorfinn S.; PIERRE, Tracey; RASMUSSEN, Morten; CAMPOS, Paula F.; DAMGAARD, Peter Barros de; ALLENTOFT, Morten E.; LINDO, John; METSPALU, Ene; RODRÍGUEZ-VARELA, Ricardo; MANSILLA, Josefina; HENRICKSON, Celeste; SEGUIN-ORLANDO, Andaine; MALMSTRÖM, Helena; STAFFORD JÚNIOR, Thomas; SHRINGARPURE, Suyash S.; MORENO-ESTRADA, Andrés; KARMIN, Monika; TAMBETS, Kristiina; BERGSTRÖM, Anders; XUE, Yali; WARMUTH, Vera; FRIEND, Andrew; SINGARAYER, Joy; VALDES, Paul; BALLOUX, Francois; LEBOREIRO, Ilán; VERA, Jose Luis; RANGEL-VILLALOBOS, Hector; PETTENER, Davide; LUISELLI, Donata; DAVIS, Loren G.; HEYER, Evelyne; ZOLLIKOFER, Christoph P. E.; PONCE DE LEÓN, Marcia S.; SMITH, Colin I.; GRIMES, Vaughan; PIKE, Kelly-Anne; DEAL, Michael; FULLER, Benjamin; ARRIAZA, Bernardo; STANDEN, Vivien; LUZ, Maria F.; RICAUT, Francois; GUIDON, Niède; OSIPOVA, Ludmila P.; VOEVODA, Mikhail I.; POSUKH, Olga L.; BALANOVSKY, Oleg; LAVRYASHINA, Maria; BOGUNOV, Yuri; KHUSNUTDINOVA, Elza; GUBINA, Marina; BALANOVSKA Elena; FEDOROVA, Sardana; LITVINOV, Sergey; MALYARCHUK, Boris; DERENKO, Miroslava; MOSHER, M. J.; ARCHER, David; CYBULSKI, Jerome; PETZELT, Barbara; MITCHELL, Joycelynn; WORL, Rosita; NORMAN, Paul J.; PARHAM, Peter; KEMP, Brian M.; KIVISILD, Toomas; TYLER-SMITH, Chris; SANDHU, Manjinder S.; CRAWFORD, Michael; VILLEMS, Richard; SMITH, David Glenn; WATERS, Michael R.; GOEBEL, Ted; JOHNSON, John R.; MALHI, Ripan, S.; JAKOBSSON, Mattias; MELTZER, David J.; MANICA, Andrea; DURBIN, Richard; BUSTAMANTE, Carlos D.; SONG, Yun S.; NIELSEN, Rasmus; WILLERSLEV, Eske. Genomic evidence for the Pleistocene and recent population history of Native Americans. Science, Washington, v. 349, n. 6250, p. aab3884, Aug. 2015. DOI: https://doi.org/10.1126/ science.aab3884.

RASMUSSEN, Morten; SIKORA, Martin; ALBRECHTSEN, Anders; KORNELIUSSEN, Thorfhinn Sand; MORENO-MAYAR, J. Víctor; POZNIK, G. David; ZOLLIKOFER, Christoph P. E.; PONCE DE LEÓN, Marcia S.; ALLENTOFT, Morten E.; MOLTKE, Ida; JÓNSSON, Hákon; VALDIOSERA, Cristina; MALHI, Ripan S.; ORLANDO, Ludovic; BUSTAMANTE, Carlos D.; STAFFORD JUNIOR, Thomas W.; MELTZER, David J.; NIELSEN, Rasmus; WILLERSLEV, Eske. The ancestry and affiliations of Kennewick Man. Nature, London, v. 523, n. 7561, p. 455-464, June 2015. DOI: https://doi.org/10.1038/nature14625.
ROOSEVELT, Anna C.; HOUSLEY, Rupert A.; SILVEIRA, Maura Imazio da; MARANCA, S.; JOHNSON, R. Eighth millenium pottery from a prehistoric shell midden in the Brazilian Amazon. Science, Washington, v. 254, n. 5038, p. 1621-1624, Dec. 1991. DOI: https:// doi.org/10.1126/science.254.5038.1621.

SANTOS, Janaína Carla dos. O Quaternário do Parque Nacional Serra da Capivara e entorno, Piauí, Brasil: morfoestratigrafia, sedimentologia, geocronologia e paleoambientes. 2007. Tese (Doutorado em Geociências) - Universidade Federal de Pernambuco, Recife, 2007.

SANTOS, Janaína Carla dos; FELICE, Gisele Daltrini; BRITO, Silvio Luiz Miranda; BARRETO, Alcina Magnólia Franca; SUGUIO, Kenitiro; LAGE, Maria Conceição Soares Meneses; TATUMI, Sonia Hatsue. Dados sedimentológicos e geocronológicos do sítio arqueológico Toca do Gordo do Garrincho, Parque Nacional Serra da Capivara, Piauí. In: CONGRESSO DA ASSOCIAÇÃO BRASILEIRA DO ESTUDO DO QUATERNÁRIO, 10., 2005, Guarapari. Anais [...]. Guarapari: ABEQUA, 2005. 1 CD-ROM.

SANTOS, Marcos César Pereira. A jazida arqueológicopaleontológica Toca da Janela da Barra do Antonião: estratigrafia e indústria lítica (Piauí, Brasil). 2012. Dissertação (Mestrado em Quaternário e Pré-história) - Instituto Politécnico de Tomar, Universidade de Trás-os-Montes e Alto Douro, Portugal, 2012.

SANTOS, M. G. C. M. dos; ROCHA, J. S. Relatório da análise tipológica do material lítico dos sítios arqueológicos do Sudeste do Piauí. Cadernos de Pesquisa, São Paulo, v. 3, p. 103-200, 1982.

SCHMITZ, Kamille R. A review of bioarchaeological thought on the Peopling of the New World. In: BEATON, C. Michael; GEOFFREY, A. Clark; YESNER, David R.; PEARSON, Georges A. (ed.). The settlement of the American continent: a multidisciplinary approach to human biogeography. Tucson: University of Arizona Press, 2004. p. $64-75$

SCHMITZ, Pedro Ignácio; ROSA, André Osório; BITENCOURT, Ana Luísa Vietti. Arqueologia nos cerrados do Brasil Central: Serranópolis III. Pesquisas-Série Antropologia, São Leopoldo, n. 60, p. 3-286, 2004.

SOUSA, João Carlos Moreno de; ARAUJO, Astolfo Gomes de Mello. Microliths and polished stone tools during the Pleistocene-Holocene transition and early Holocene in South America: the Lagoa Santa lithic industry. PaleoAmerica, London, v. 4, n. 3, p. 219-238, Oct, 2018. DOI: https://doi.org/10.1080/20555563.2018.1531350.

STRAUSS, André; OLIVEIRA, Rodrigo Elias; GRATAO, Marina; COSTA, Amélie da; FOGAÇA, Emílio; BÖEDA, Eric. Human skeletal remains from Serra da Capivara, Brasil: review of the available evidence and report on new findings. In: HARVATI, Katerina; JÄGER, Gerhard; REYES-CENTENO, Hugo (ed.). New perspectives on the peopling of the New World. Tübingen: Kerns Verlag, 2018. p. 153-171.

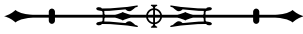


TAYLOR, Royal Ervin. Radiocarbon dating: an Archaeological perspective. Orlando: Academic Press, 1987.

VALLADAS, Héléne; MERCIER, Norbert; MICHAB, M.; JORON, Jean Louis; REYSS, Jean Louis; GUIDON, Niède. TL age-estimates of burnt quartz pebbles from the Toca do Boqueirão da Pedra Furada (Piauí, Northeastern Brazil). Quaternary Science Reviews, Amsterdam, v. 22, n. 10/13, p. 1253-1257, May 2003. DOI: https:// doi.org/10.1016/S0277-3791(03)00029-5.

VIALOU, Denis; BENABDELHADI, Mohammed; FEATHERS, James; FONTUGNE, Michel; VIALOU, Águeda Vilhena. Peopling South America's centre: the late Pleistocen site of Santa Elina. Antiquity, Cambridge, v. 91, n. 358, p. 865-884, Aug. 2017. DOI: https://doi. org/10.15184/aqy.2017.101.

WALKER, Mike; JOHNSEN, Sigfus; RASMUSSEN, Sune Olander; POPP, Trevor; STEFFENSEN, Jørgen-Peder; GIBBARD, Phil; HOEK, Wim; LOWE, John; ANDREWS, John; BJÖRCK, Svante; CWYNAR, Les C.; HUGHEN, Konrad; KERSHAW, Peter; KROMER, Bernd; LITT, Thomas; LOWE, David J.; NAKAGAWA, Takeshi; NEWNHAM, Rewi; SCHWANDER, Jakob. Formal definition and dating of the GSSP (Global Stratotype Section and Point) for the base of the Holocene using the Greenland NGRIP ice core, and selected auxiliary records. Journal of Quaternary Science, Hoboken, v. 24, n. 1, p. 3-17, 2009. DOI: https://doi.org/10.1002/jqs.1227.
WANG, Xianfeng; AULER, Augusto S.; EDWARDS, R. Lawrence; CHENG, HAI; CRISTALLI, Patricia S.; SMART, Peter L.; RICHARDS, David A.; SHEN, Chuan- Chou. Wet periods in northeastern Brazil over the past $210 \mathrm{kyr}$ linked to distant climate anomalies. Nature, London, v. 432, n. 7018, p. 740-743, Dec. 2004.

WATERS, Michael R.; STAFFORD JÚNIOR, Thomas Wier. The first Americans: a review of the evidence for the Late-Pleistocene peopling of the Americas. In: GRAF, Kelly E.; KETRON, Caroline V.; WATERS, Michael R. (ed.). Paleoamerican odissey. College Station: Texas A\&M University, 2014. p. 541-560.

WATERS, Michael R.; STAFFORD JÚNIOR, Thomas Wier. Redefining the Age of Clovis: implications for the peopling of the Americas. Science, Washington, v. 315, n. 5815, p. 1122-1126, Feb. 2007. DOI: https://doi.org/10.1126/science.1137166.

ZEGURA, Stephen L.; KARAFET, Tatiana M.; ZHIVOTOVSKY, Lev A.; HAMMER, Michael F. High-resolution SNPs and microsatellite haplotypes point to a single, recent entry of Native American $Y$ chromosomes into the Americas. Molecular Biology and Evolution, Oxford, v. 21, n. 1, p. 164-175, Jan. 2004. DOI: https:// doi.org/10.1093/molbev/msh009. 


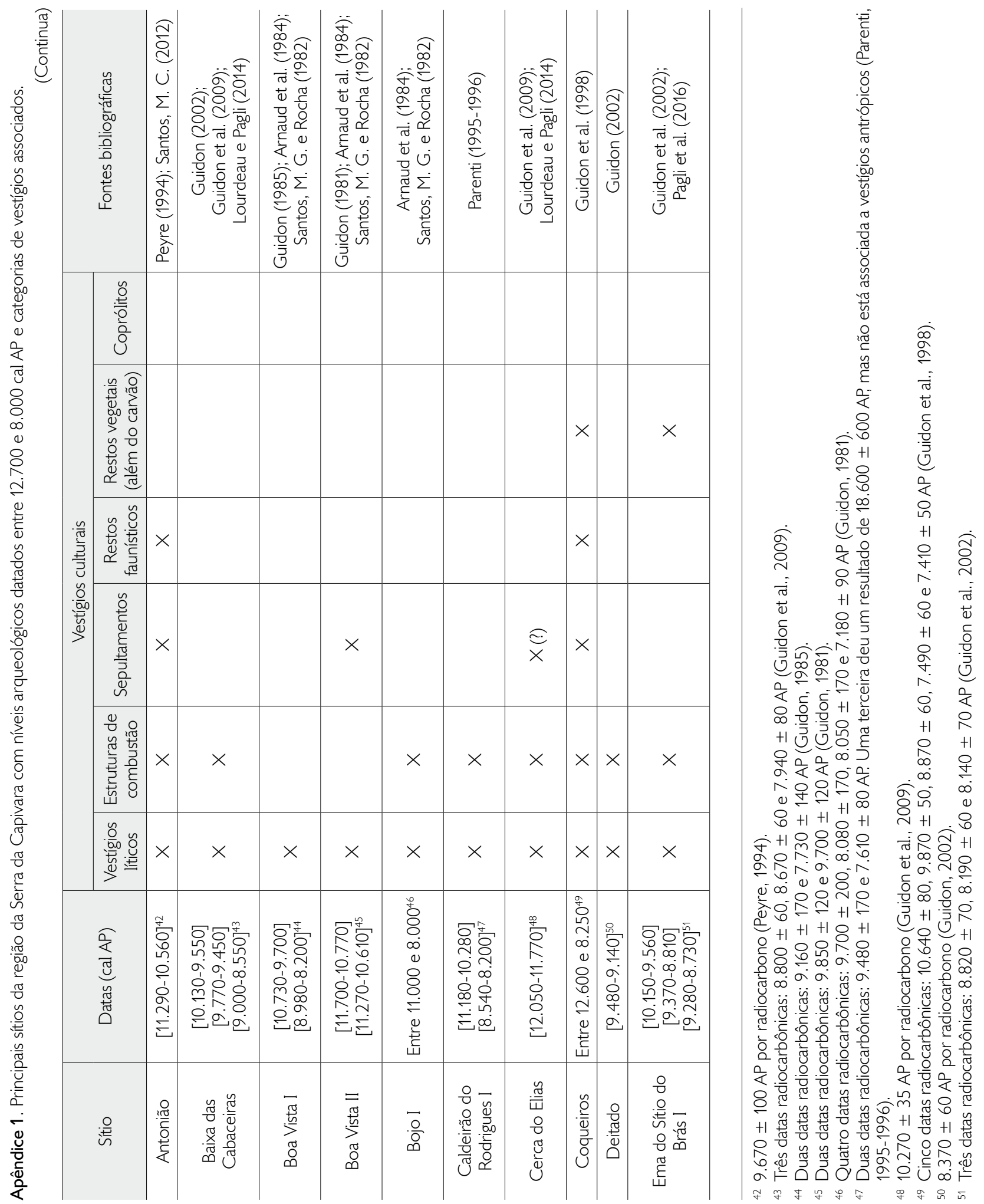




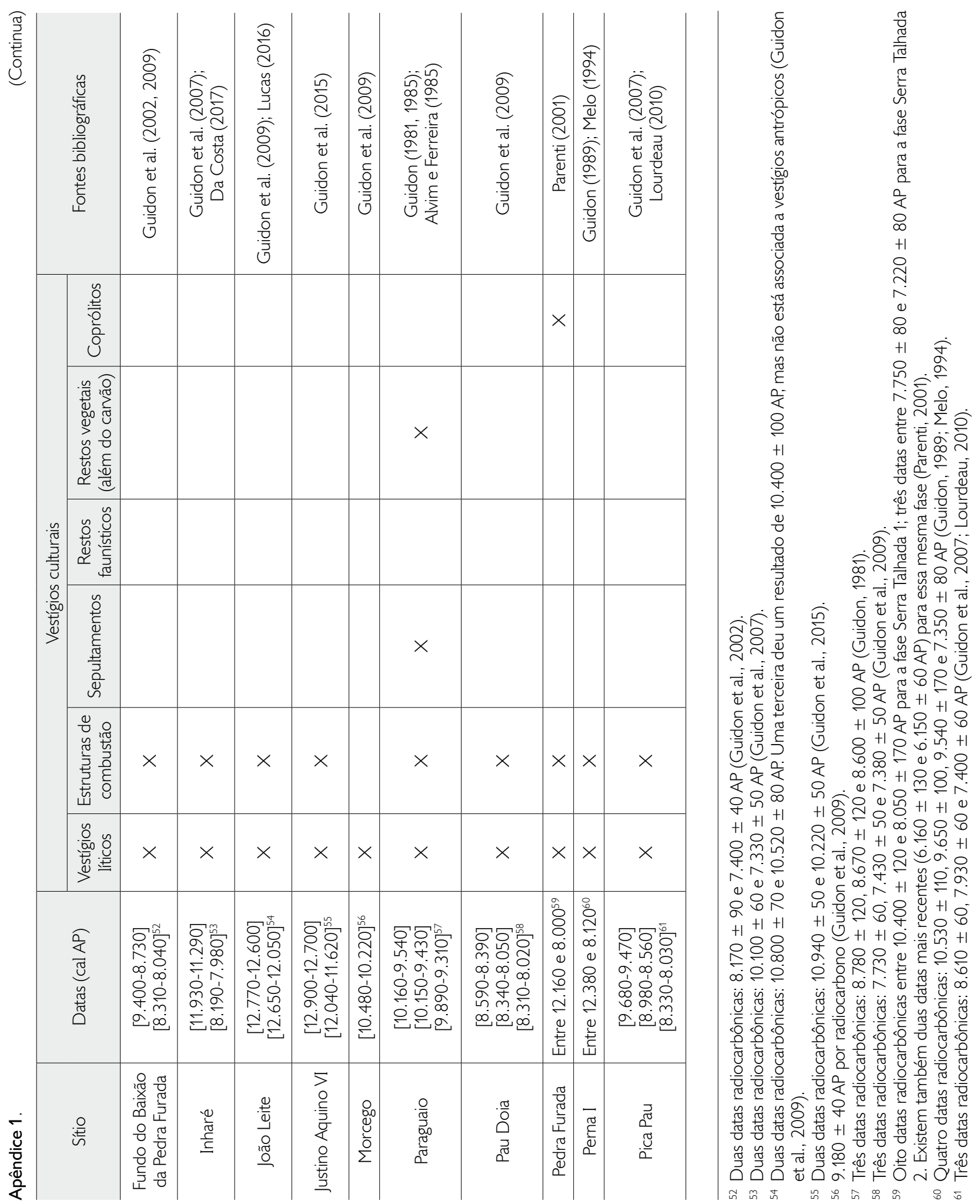



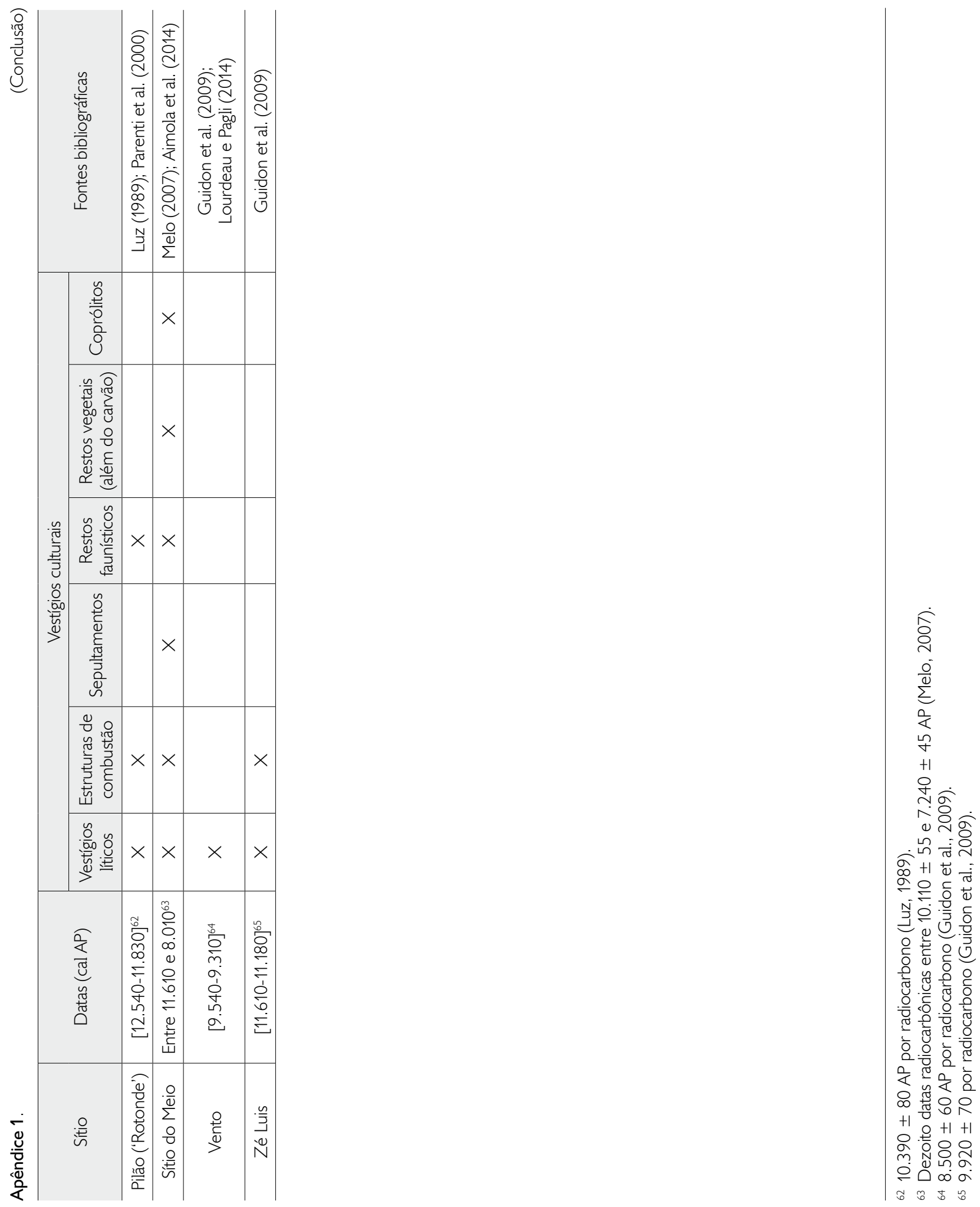